\title{
Rationalist architecture in rural villages: petro-morphological characterization of natural asbestos fibers in decorative plas- ters used for artificial stones
}

\author{
${ }^{1}$ Department of Physics and Earth Sciences, University of Ferrara - via Saragat 1, 44121 Ferrara, Italy; *Corresponding author, E-mail: \\ VirginiaLattaolttvgn@unife.it \\ ${ }^{2}$ CNR-IGAG, Sede di Roma, c/o Dipartimento di Scienze della Terra, Sapienza Università di Roma, P. le A. Moro, 500185 Roma Italy \\ ${ }^{3}$ SOCOTEC ITALIA, Ferrara Department - via Annibale Zucchini 69, 44122 Ferrara, Italy \\ ${ }^{4}$ ISAC-CNR Institute of Atmospheric Sciences and Climate of the National Research Council of Italy, Via Piero Gobetti, 101, 40129 Bologna, Italy
}

(Received: January 31, 2020; Revised accepted: July 17, 2020)

https://doi.org/10.18814/epiiugs/2020/0200s08

At the beginning of the twentieth century, artificial stones became commonly used as structural building materials, masonry materials, and architectural decorative elements. The main purpose of this work was to characterize the building materials used in a historical building in Codigoro, a small town near Ferrara, northeastern Italy. This building was constructed according to the Italian rationalist rules for monumental architecture and is an example of the rationalist architecture found in rural villages, which uses innovative materials and decorations including artificial stone. The samples analyzed in this work were imitation natural stone, such as "fake travertine" and "fake Ceppo di Grè", composed of reinforced concrete slabs coated with white mortar. Asbestos minerals have been observed in the fillers in these materials. Petrographic, mineralogical, and chemical characterization of samples of artificial stones and concrete was performed with optical transmitted light microscopy, scanning electron microscopy-energy dispersive spectroscopy, and $X$-ray diffraction analyses. The results revealed chemical and biological degradation in almost all the artificial stones examined and enabled identification of the presence of calcite, iron oxychloride complexes, and asbestos lizardites used as fillers in two of the analyzed samples. This study aimed to describe a general investigation methodology used to examine the artificial stone façades of the Ex Casa del Fascio of Codigoro, whose architecture is particularly representative of the rationalist architecture in rural villages. The results highlight the relevance of compatible and suitable conservation measures that should be monitored during all restoration interventions to minimize post-degradation fracturing and transformation into elements harmful to human health and the environment.

\section{Introduction}

During the nineteenth century, the process of construction rationalization, together with its economic implications, led to the introduction of new construction systems as well as new industrial materials, which were sometimes used in conjunction with, or as substitutes for, traditional materials. Artificial stone appeared in the early nineteenth century and represents a link between traditional stone construction and the newer reinforced concrete technique (Bertolazzi, 2013). The use of artificial stone, together with unconventional materials (iron, glass, or concrete), spread throughout European architecture from the end of the nineteenth century. Artificial stone was broadly present at the beginning of the twentieth century in social and economic contexts, as an expression of the middle-class cultural evolution, which enabled building prestigious buildings inexpensively by using modern hydraulic binders (cements) for the decorative elements. The term "artificial stone" describes materials obtained by mixing sand, gravel, and water with lime, Portland cement, or plaster to produce a material resembling stone (Pecchioni et al., 2005; Stefanidou et al, 2015). This material provided an economical alternative to natural lithic ornamental luxury materials, owing to the reuse of waste material (Mazzeo, 2018). After the invention of Portland cement in the United Kingdom at the end of the nineteenth century, the use of artificial stone became widespread, and residential and industrial architecture (Pecchioni et al., 2005; Fatiguso et al., 2013) were transformed with the development of the Art Nouveau style in Europe. These materials provided high aesthetic value and allowed for decorative elements to be used in public and industrial architecture, as well as in the residential sector (Mazzeo, 2018). This artificial building material could be mass-produced enabled high reproducibility in short time periods, with low environmental and economic costs; ornamental elements with properties similar to those of specific stones could be created in the desired shapes and sizes. The construction techniques used for artificial stone 
decorations and their use in the cultural heritage were well described in many European architecture magazines, as indicated by Baldazzi, 2012. The production of artificial stones in Italy first appeared in 1881 at the Industrial Expo in Milan (Sandrolini et al., 2011).

At the beginning of the twentieth century, the production of artificial stone became well known, and many production methods were issued in Italy. Several patents in this period describe the use of asbestos fillers to improve the physical-mechanical features, polishability, and durability of cement decorative elements, such as the GB 277884 patent (1927) for mold improvement in the construction of artificial stone blocks. Artificial stone was used throughout Italy (Biscontin and Driussi, 2006; Rocchi, 2012), and studies of materials from different areas in Italy have revealed that the mixture was often prepacked and modified according to the desired prototype (Michelacci, 2000; Di Biase et al., 2008; Dameri, 2012; Monica and Bergamaschi 2019). As a result, unconventional and cost-effective materials (some of which have recently been identified as harmful materials) were used to create the decorative elements of buildings.

Asbestos is a general commercial-industrial term used to describe a group of naturally occurring silicate minerals of fibrous or asbestiform habit. These minerals can be divided into two groups: (i) serpentine, which includes only the asbestos chrysotile polymorph, and (ii) amphibole, which includes the actinolite, tremolite, anthophyllite, crocidolite (riebeckite), and amosite (cummingtonite-grunerite) asbestos varieties. The other serpentine polymorphs (i.e., lizardite and antigorite) and other amphiboles (i.e., fluoro-edenite) or zeolites (i.e., erionite) are not regulated and therefore are termed "asbestiform." Because of their exceptional attributes (high tensile strength, flexibility, and chemical and heat resistance), asbestos minerals have been used since ancient times as raw materials to produce a large variety of materials and objects. The inherent properties of asbestos fibers appear to contribute to the toxicity of these mineral particles when they are lodged inside the human respiratory system (Stanton et al., 1981; Mossman et al., 1990; Wylie et al., 1993; Nolan et al., 2001; Constantopoulos, 2008; Harper 2008; Murray and Nelson, 2008; Baumann and Ambrosi, 2013; Bloise et al., 2016; Pollastri et al., 2016; Turci et al., 2016; Bloise et al., 2020). Ophiolitic rocks may contain various amounts of asbestos minerals (e.g., Skarpelis and Dabitzias, 1987; Ross and Nolan, 2003; Skarpelis, 2006; Rigopoulos et al., 2008; Punturo et al., 2015), among which chrysotile is usually the most common. Chrysotile can be found in many types of serpentinized ultrabasic rock, either as alteration product of olivine and/or orthopyroxene, or as veins crosscutting the rock. Among ophiolitic rocks, metabasite may also contain considerable amounts of amphibole asbestos fibers, principally actinolite and/or tremolite, which represent the transformation products of clinopyroxene (e.g., Tsikouras et al., 2005; Rigopoulos et al., 2006). Asbestos fibers are thin, needle-like crystals that may vary widely in diameter from millimeters to micrometers. The biologically important "critical" fibers are those with the following shape criteria: length $\geq 5 \mu \mathrm{m}$, diameter (width) $\leq 3 \mu \mathrm{m}$, and length to diameter ratio (aspect ratio) $\geq 3: 1$ (World Health Organization, 1986; National Institute for Occupational Safety and Health, 2008; International Agency for Research on Cancer, 2009). Asbestos minerals in the ophiolitic rocks used as aggregates for road construction, railway ballast, concrete, and other applications are particularly dangerous for public health, because fibers of the sizes described above may be released into the air during in-service deterioration of aggregates and may be inhaled into the lungs, thus causing serious health problems (Bloise et al., 2016; Punturo et al., 2019).

Italian monumental rationalist architecture has recently become a subject of particular interest in the study of its constituent materials (Fiorentino et al., 2015). Codigoro and Tresigallo, two small towns near Ferrara in northeastern Italy, have well-known examples of the Italian monumental architecture from the twentieth century and of rationalist architecture (Caprotti, 2007), which widely used artificial stone. Moreover, these two municipalities have examples of Italian architecture in the fascist period (Viganò, 1971; Baldazzi, 2012). On May $20^{\text {th }}$ and $29^{\text {th }} 2012$, both these towns, as well as Ferrara and most parts of the Emilia Romagna region, were affected by two seismic events that damaged buildings in the historic centers and rural areas (Courard et al., 2012; Freire-Lista et al., 2019). This work was part of a reconstruction and post-seismic restoration project involving several historic rationalist architectural buildings damaged by these earthquakes. Our focus was on the Ex Casa del Fascio of Codigoro. According to Tamiozzo (2009), the ability to distinguish between original building materials and those used after restoration is fundamental for making effective and respectful choices to ensure effective intervention. Accordingly, with a suitable stability plan for damaged historical buildings in place, we performed a chemical and micro-structural investigation on the construction materials (and artificial stones) used in rationalist buildings. As suggested by Varas-Muriel et al. (2015), mineralogical and petrographic characterization of the materials used in buildings is a helpful tool to identify the best and most cost-effective strategies for removing or reducing degradation agents, as well as for predicting behavior over time, in the presence of agents of material degradation.

Many analyses were performed to understand the probable degradation resulting from reusing building elements and materials and to investigate the presence of asbestos minerals. This particular study was justified because, in the period of rationalist architecture, some artificial stone materials were produced from products potentially containing materials with harmful health effects (Bloise et al., 2016). Determining the presence of asbestos mineral phases is important because they pose health risks.

\section{Materials and Methods}

According to well established methodological procedures (Binda et al., 2000; McCann and Forde, 2001; Schuller, 2003; Warkea, 2003), an investigation system to support the study of artificial stone façade components should be based on preliminary analysis using historical research, geometry surveys, and visual assessment. The diagnostic process may involve onsite destructive/non-destructive and laboratory tests (Sandrolini, 2005; Bartz, 2012).

To qualify the mixtures and assess the decay, we characterized the materials through laboratory analyses. Preliminary macroscopic observation of all samples was fundamental to support the interpretation of the results obtained from onsite non-destructive tests.

Petrographic and mineralogical characterization of the binders, aggregates, and microstructural and morphological observations was performed on samples from the ground floor of the external façade of the Ex Casa del Fascio building in Codigoro (near the city of Ferrara). This building is a typical example of rationalist architecture in rural 


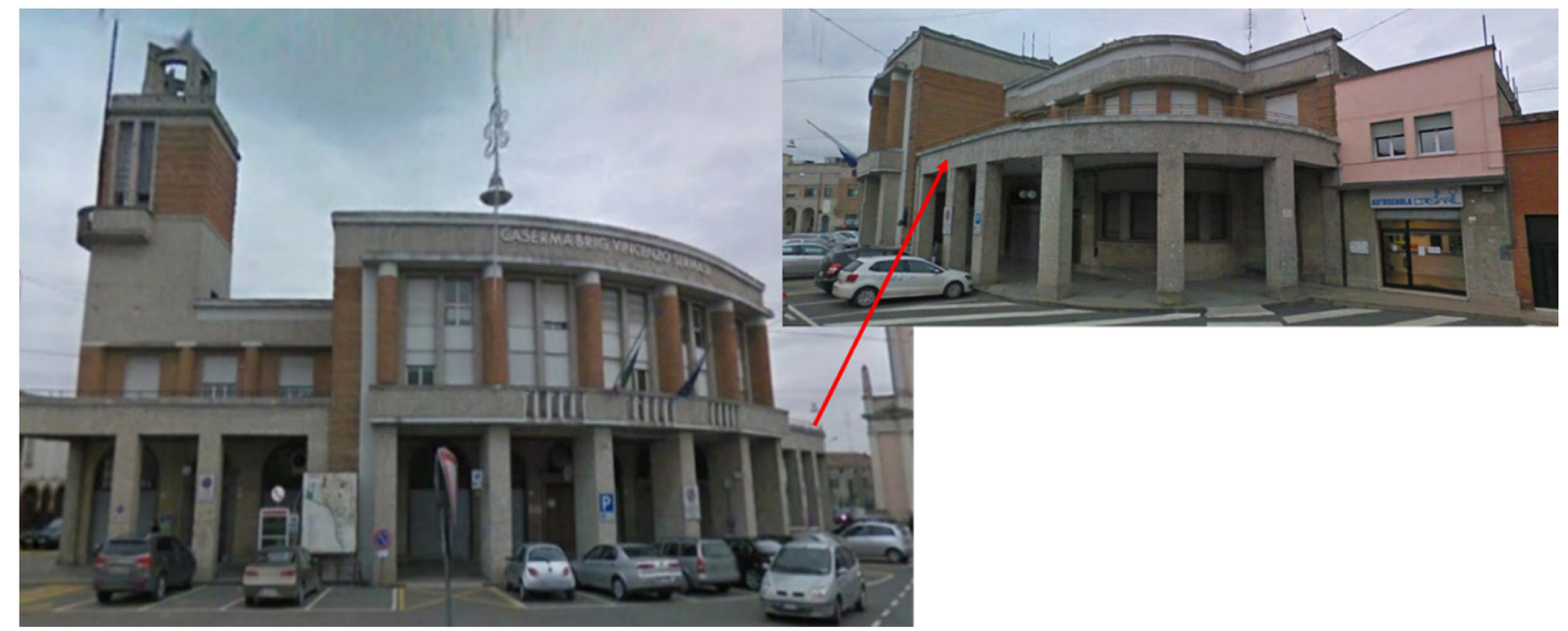

Figure 1. The Ex Casa del Fascio building façade, Codigoro, near to Ferrara, northeastern Italy.

areas. Its ground floor is clad with artificial stone slabs, used as decorative stones, built above a reinforced concrete base. These slabs were severely damaged because of dilation phenomena caused by the highly corroded reinforcements. To fix this damage, several restoration oper- ations were performed before 1992; these interventions were performed with mortar mixes containing fibrous fillers, whereas the most recent restoration operations used mortars without fillers.

Monumental balconies overlooking the main entrance are a typical

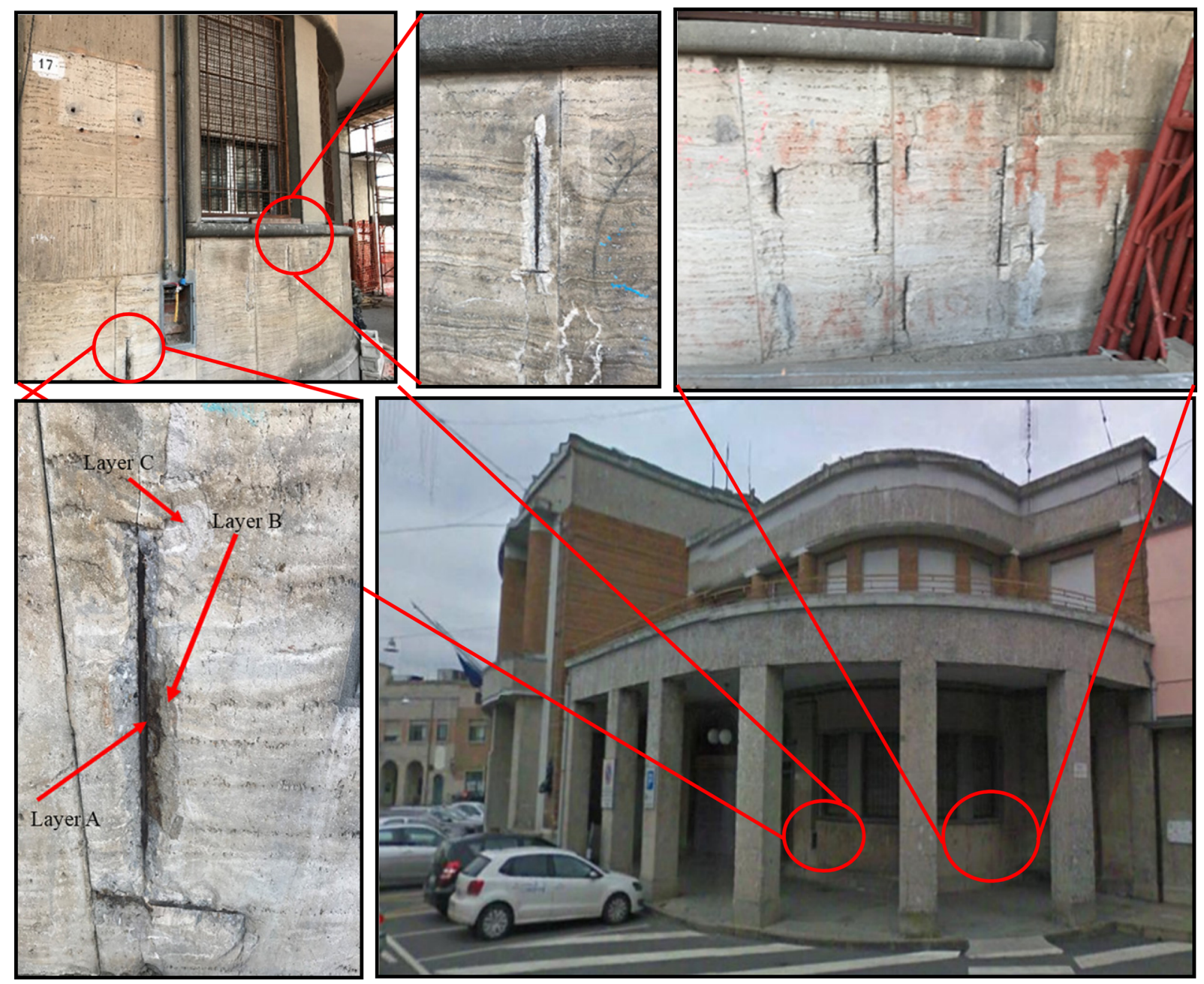

Figure 2. "Fake travertine" sample CO1. This artificial stone is present in the ground floor of the Ex Casa del Fascio building and is composed by 3 different layers: layer A (the inner), layer B (above layer A) and layer C the most superficial. 
element with high symbolic value in public buildings built during the rational and neoclassical architecture periods. The Ex Casa del Fascio building follows that architectural rule. The monumental colonnade balcony in artificial stone imitating marble is one of the most relevant elements of this building (Fig. 1).

\section{Sampling}

Samples were collected at different locations from the ground level up, and differences among the types of artificial stone decorative elements and exposure to rainwater were considered.

Although well established diagnostic procedures and techniques exist for natural stone, for artificial stone components, the diagnostic process should be carefully planned to consider specific features such as mixtures, installation and connection methods, and the mechanisms of interaction with reinforcement and support materials.

For "fake travertine" artificial stone, CO1, the sampling was mainly performed on the ground floor slabs in the areas near fractures where the reinforcement bars of the basement concrete produced expansion phenomena due to weathering (Fig. 2).

Samples of "fake Ceppo di Grè" artificial stone, $\mathrm{CO} 2, \mathrm{CO} 4$, and $\mathrm{CO} 7$, were collected from the inner parts of the pillars (Fig. 3).

The artificial stone materials used for building the monumental colonnade balcony has been covered by successive layers of a mixture of gray cement and lime; for this reason the materials below this strata were sampled as $\mathrm{CO} 6$ (Fig. 4).

Sample CO3 came from the replacement materials used to infill cracks, which was easily recognizable because of the dark gray color, relief with respect to the surfaces of the slabs, and thin appearance (Fig. 5).

Details of collected samples are listed on Table 1.

\section{Chemical and Mineralogical Characterization}

A petrographic study of the samples was performed to determine the composition and granulometry of the aggregate and to verify the potential presence of asbestos minerals used as fillers. Petrographic observations and measurements were performed with optical trans-
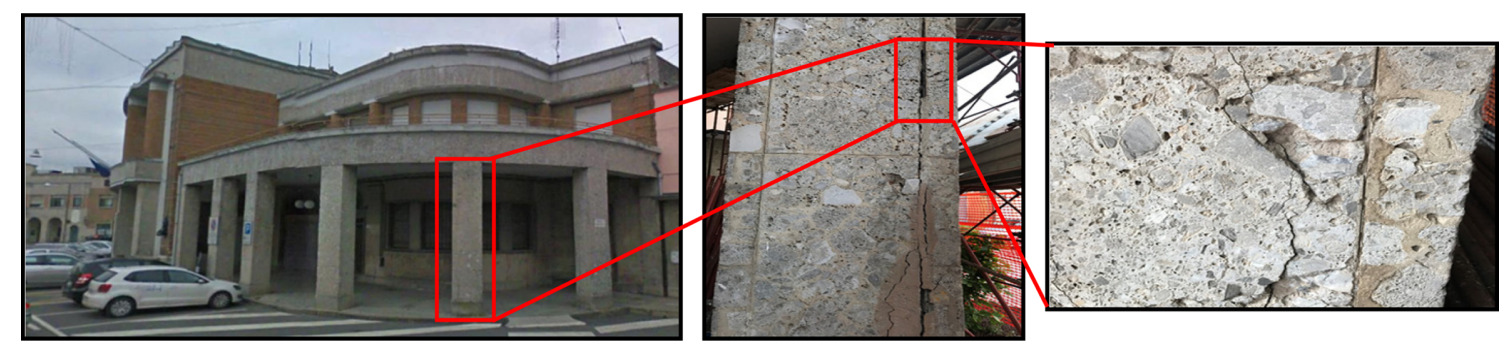

Figure 3. "Fake Ceppo di Grè" samples CO2, CO4, CO7. Big clasts of carbonate rocks (limestone and dolomite in prevalence). Damaged areas are in correspondence of emerging oxidized reinforcement bars.
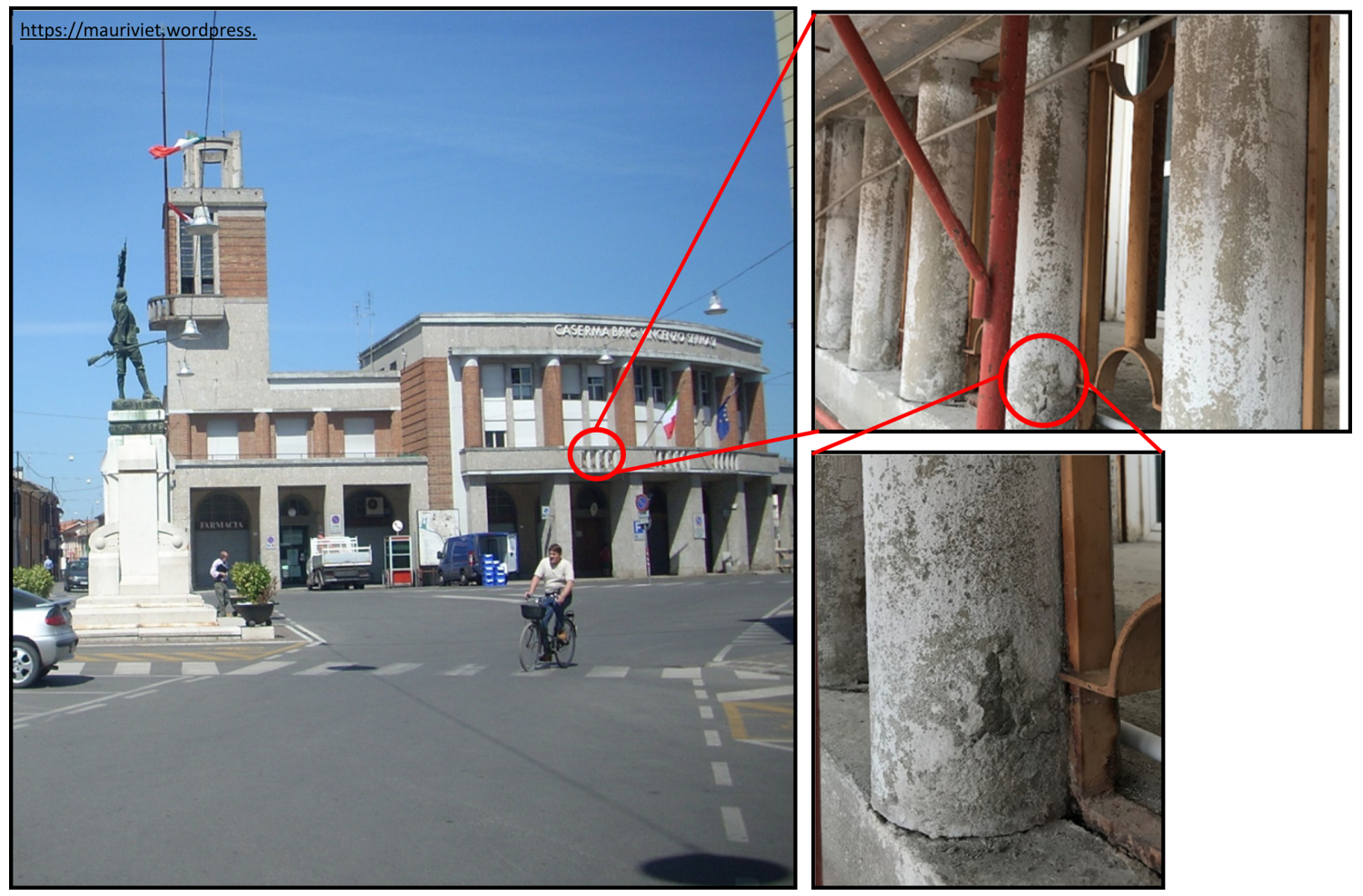

Figure 4. Fake limestone sample CO6. The first-floor colonnade. The white strata visible in the pictures is not coeval with the columns building, it has been applied on at the end of the twentieth centuries during restoration operations. 

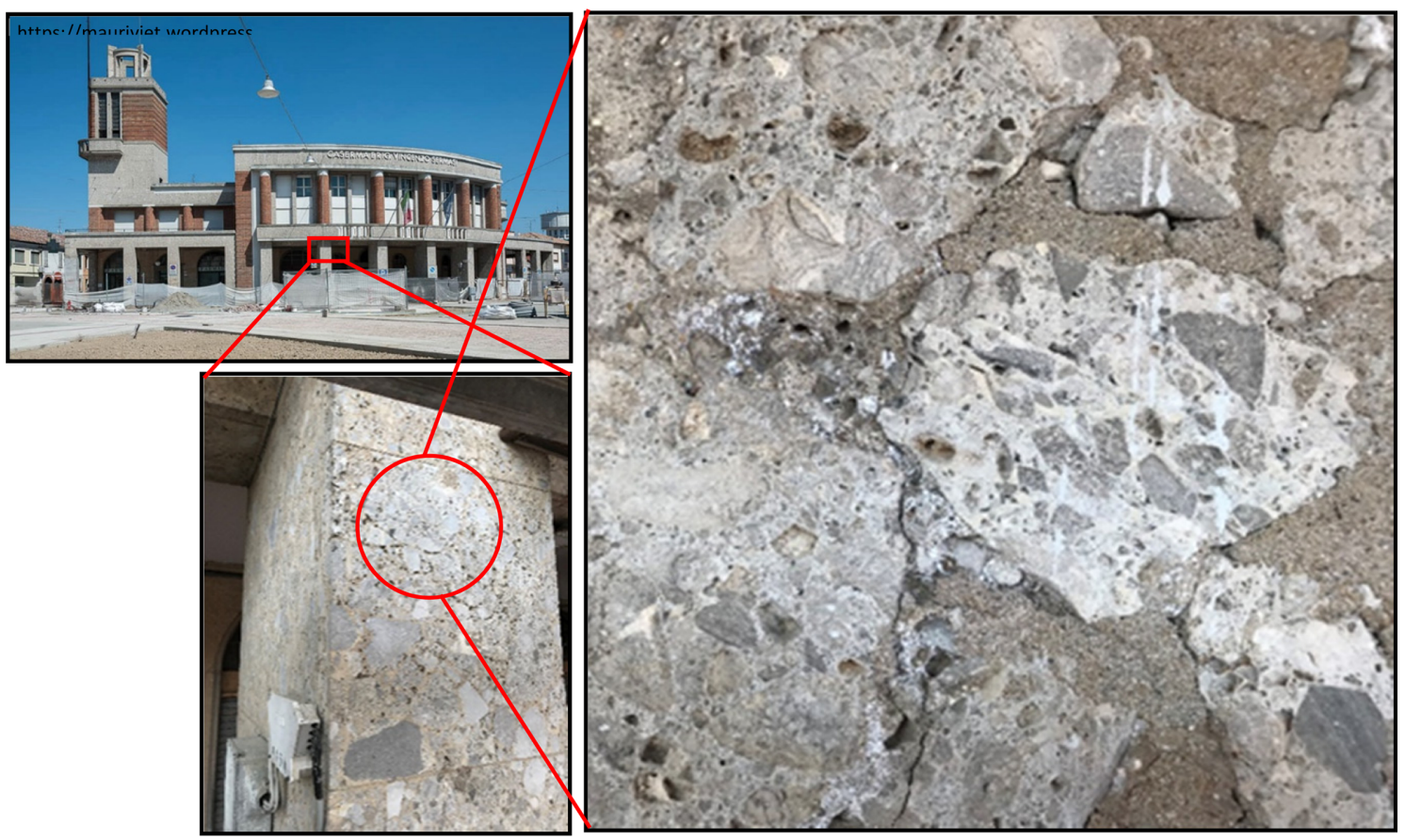

Figure 5. Concrete infilling mortar sample CO3. The Ex casa del Fascio building has been affected by damages caused by the earthquakes in May 2012, but before these events it was been subjected to restore operations not always made following the correct procedures for historical building.

Table 1. Details of analyzed samples

\begin{tabular}{|c|c|c|c|c|c|c|}
\hline Sample & Samples Classification & $\begin{array}{c}\text { Height from ground } \\
\text { level }(\mathrm{m})\end{array}$ & Protection from rain & Original & Restoration & Type of Analyses \\
\hline $\operatorname{CO} 1(a, b, c)$ & Fake travertine & $0.95 \mathrm{~cm}-1.10 \mathrm{~m}$ & Sheltered & $\mathrm{X}$ & & OPLM SEM-EDS \\
\hline $\mathrm{CO} 2(\mathrm{a}, \mathrm{b}, \mathrm{c}, \mathrm{d})$ & Fake Ceppo di Gré & $1.70-1.75 \mathrm{~m}$ & Partly sheltered & $\mathrm{X}$ & & OPLM \\
\hline $\mathrm{CO} 3 \mathrm{e}$ & Concrete infilling mortar & $0.40-0.45 \mathrm{~m}$ & Partly sheltered & & $\mathrm{X}$ & OPLM SEM-EDS XRD \\
\hline $\mathrm{CO} 4(\mathrm{a}, \mathrm{b})$ & Fake Ceppo di Gré & $1.70-1.75 \mathrm{~m}$ & Partly sheltered & $\mathrm{X}$ & & OPLM SEM-EDS \\
\hline $\operatorname{CO6}(a, b, c)$ & Fake limestone used in columns & $0.20-0.25 \mathrm{~m}$ & Partly sheltered & $\mathrm{X}$ & & OPLM SEM-EDS \\
\hline $\mathrm{CO} 7 \mathrm{a}$ & Fake Ceppo di Gré & $0.30-0.35 \mathrm{~m}$ & Exposed to the weathering & $\mathrm{X}$ & & OPLM SEM-EDS \\
\hline
\end{tabular}

mitted light microscopy (OTLM) with an OPLOPTIKA B510 POLAOS and a stereomicroscope SZ6745TR. Both microscopes were equipped with a MOTICAM $25005.0 \mathrm{M}$ pixel webcam operated by Motic Images Plus 2.0 ML software. Microscopic observations were performed on polished thin sections of whole rock samples prepared according to the standard procedures established for Cultural Heritage (UNI 11176:2006, 2006; Di Biase et al., 2008; Tamiozzo, 2009; Fatiguso et al., 2013). Scanning electron microscopy (SEM) observations on thin sections and fragments of samples were performed with a model ZEISS EVO MA 15, coupled with an energy dispersive Xray spectroscopy (EDS) system (Aztec Oxford apparatus, SDD detector, WD $8.5 \mathrm{~mm}$, EHT $20 \mathrm{kV}$ ), with an LaB6 filament as the electron source, and used for microstructural characterization and qualitative determination of chemical composition. SEM images in back-scattered detector imaging mode were used to study the morphological and topographical features of the samples. SEM imaging is an efficient tool used to determine the chemistry of amphibole fibers/particles (diameter $>$ $3 \mu \mathrm{m}$ ). By extension, the combination of polarized light microscopy and SEM coupled to EDS analyses enabled efficient identification of amphibole fragments and/or fibers larger than $3 \mu \mathrm{m}$. Additionally, the qualitative EDS analyses indicated extensive variations in textures, morphologies, crystal growth patterns, habits, and crystal structures.

Compared with OTLM, SEM allows for imaging and identification of smaller fibers, and it can be used to evaluate the morphological and chemical composition of asbestiform minerals. In contrast to OTLM, the ability of SEM to utilize reflected energy for imaging allows fibers adhering to other mineral surfaces to be easily observed. Asbestiform minerals are clearly identifiable, because high magnifications can be obtained (Clinkenbeard et al., 2002).

Morphological and microstructural characterization was performed with SEM analysis to detect the morphology of the particles, to determine the presence of fibers (i.e., asbestos minerals), and to identify the fiber dimensions (diameter and length) and any aggregation (e.g., presence of growth or microfractures). The morphological analysis was conducted through microanalysis to identify the chemical and mineralogical composition of the observed granules.

XRD analyses were performed with a Seifert MZIV automatic powder diffractometer equipped with a graphite monochromator operating 
at $40 \mathrm{kV}$ and $20 \mathrm{~mA}$, using $\mathrm{Cu} \mathrm{K} \alpha$ radiation. The XRD data were collected from $5^{\circ}$ to $60^{\circ} 2 \theta$ with a counting time of $8 \mathrm{~s}$ and step-size of $0.02^{\circ}$. The grinding of samples to perform the diffractometric analyses was performed in an agate mortar and pestle in humid environmental conditions to avoid dispersion of the environment fibers that might be dangerous to human health. XRD analysis was performed on a pulverized sample of replacement cement paste (Clinkenbeard et al., 2002). Although polarized microscopy and XRD are useful for preliminary identification of asbestos mineral phases, given the possible presence of asbestos minerals in these samples, SEM-EDS was considered the most powerful tool for the detailed investigation of fibrous minerals.

\section{Results}

\section{Macroscopic Characterization}

"Fake travertine" artificial stone (Fig. 2)
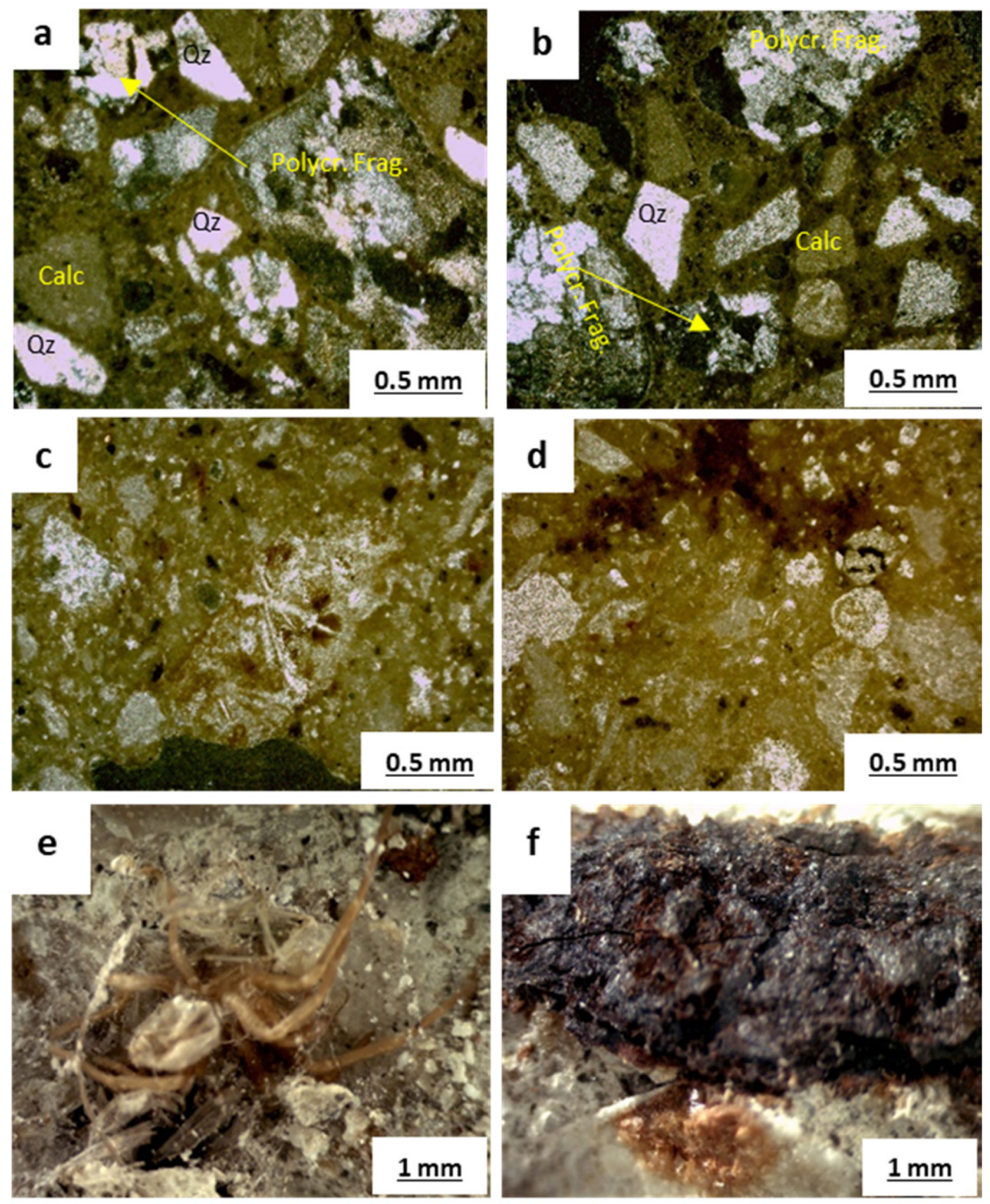

Figure 6. "Fake travertine” Sample CO1. Thin section micrographs. Layer A, examples of concrete mix with silico-carbonate aggregate a) sharp edge quartz and silicate rocks fragments; b) sharp edge quartz, silicate rocks fragment and carbonate fragments. Layer B, aggregate mainly composed by various lithotypes of carbonate rocks, such as c) light white limestone, low-round foraminifera rocks, d) well-rounded beige micritic pebbles and rare spathic calcite fragments. Reddish color should be due to presence of iron oxides and hydroxides, often deposited inside the binder in contact with the macro and micropores. Layer $C$ stereomicroscope pictures of the outer layer e) spider; $f$ ) particular of a black crust. 
Macroscopic observations of CO1 "fake travertine" artificial stone decoration revealed the presence of three layers.

i) Layer A represents the structural element of the decorative slabs and was composed of bar-reinforced well mixed concrete with homogeneous distribution of the aggregate. Thin section observations revealed that the aggregate fraction was mainly composed of a silico-carbonate fraction, with a higher prevalence of silicate than carbonate. The silicate fraction was mainly composed of fragments of polymineral rocks, such as gneiss, arenaceous-pelitic metamorphosed rocks, and a small amount of ultramafic rock fragments. Quartz, feldspars, a low percentage of micas (muscovite and biotite), and some serpentine crystals were the identified silica mineral phases. Few carbonate rock aggregates were also present (Fig. 6).

ii) Layer B represents the decorative layer, which was obtained by mixing a white cement type with white/pale yellow limestone rock. This decorative layer overlapped the reinforced concrete of layer A. Micrite grains and a low percentage of yellow limestone fragments was detected. OTLM observations indicated that this layer was composed primarily of a carbonate aggregate within a plaster mortar with the typical optical features of a hydraulic binder. The binder aggregate modal ratio was estimated to be approximately $1 / 3$ with a non-homogeneous distribution of aggregate. The aggregate was mainly composed of various lithotypes of carbonate rocks, such as light white limestone, low-round foraminifera rocks, well-rounded beige micritic pebbles, and rare spathic calcite fragments. Reddish areas were present in the mixture, owing to the presence of iron oxides and hydroxides related to steel bar reinforcement alteration phenomena (Fig. 6).

iii) Layer $\mathrm{C}$ represents the protection strata subjected to yellowing in the altered areas. Stereomicroscopic observations of the surface revealed strong biological degradation with the presence of nests of insects and fungal hyphae, together with a black crust (Fig. 6) (Randazzo et al., 2015; Chen et al., 2017; Molina et al., 2017).

\section{"Fake Ceppo di Grè” (Fig. 3)}

The natural stone material known as Ceppo di Grè is a polygenic conglomerate whose geological name is Ceppo Conglomerate (Vola et al., 2009). It crops out along all foothills of the River Po Valley and as reported by Vola et al., 2009 has been widely used as a decorative stone material in northern Italy. The artificial stone classified here as "fake Ceppo di Grè" faithfully reproduces the Lombard Breccia that crops out in the surroundings of Iseo Lake (Jadoul and Galli, 2008; Muttoni et al., 2010; Berra and Carminati, 2010; Ronchi et al, 2011).

Macroscopic observations of "fake Ceppo di Grè" artificial stones investigated in this work (samples $\mathrm{CO} 2, \mathrm{CO} 4$, and $\mathrm{CO} 7$ ) showed irregular and angular fragments with a prevalence of micritic and microsparitic carbonate rocks. In "fake Ceppo di Grè," as described for "fake travertine" slabs, regions near the damaged areas showed oxidation affecting the reinforcement bars. Because of the sizes of limestone and dolomite clasts (from $3-5 \mathrm{~cm}$ to $100 \mathrm{~cm}$ ), analysis of these samples focused on the binder. Stereomicroscopic and petrographic microscopic observations of mortars showed the yellowishgray background of the matrix, with aggregate constituted by sandy fractions. In addition to natural aggregate, some asbestos phases such as fillers (less than 1\%) were observed. Thin sections showed a medium aggregate/binding ratio in mortars binding well with mixing. The binder porosity was mainly macroscopic, with low microporosity. Extensive degradation phenomena and carbonation processes corresponded to the weathering of exposed areas. The cement matrix natural aggregate was composed mostly of carbonate aggregates, with a presence of vitrophiric slag and asbestos minerals used as reinforcement fillers. Oxides and hydroxides with black (ilmenite-magnetite) and red blood color were rare (Fig. 7).

\section{Fake limestone used for columns (Fig. 4)}

The observation of samples collected from the columns (CO6) showed a tenacious mortar consisting of a white cement with an amorphous structure and a well-classed medium silica sand aggregate enriched in serpentinite. The aggregate was characterized by the prevalence of serpentinite (around 70\%) with a minor percentage of micritic limestones, quartz, iron hydroxides, pale yellow vitrophiric slag, and green glass fragments. Degradation phenomena were absent. The aggregate/
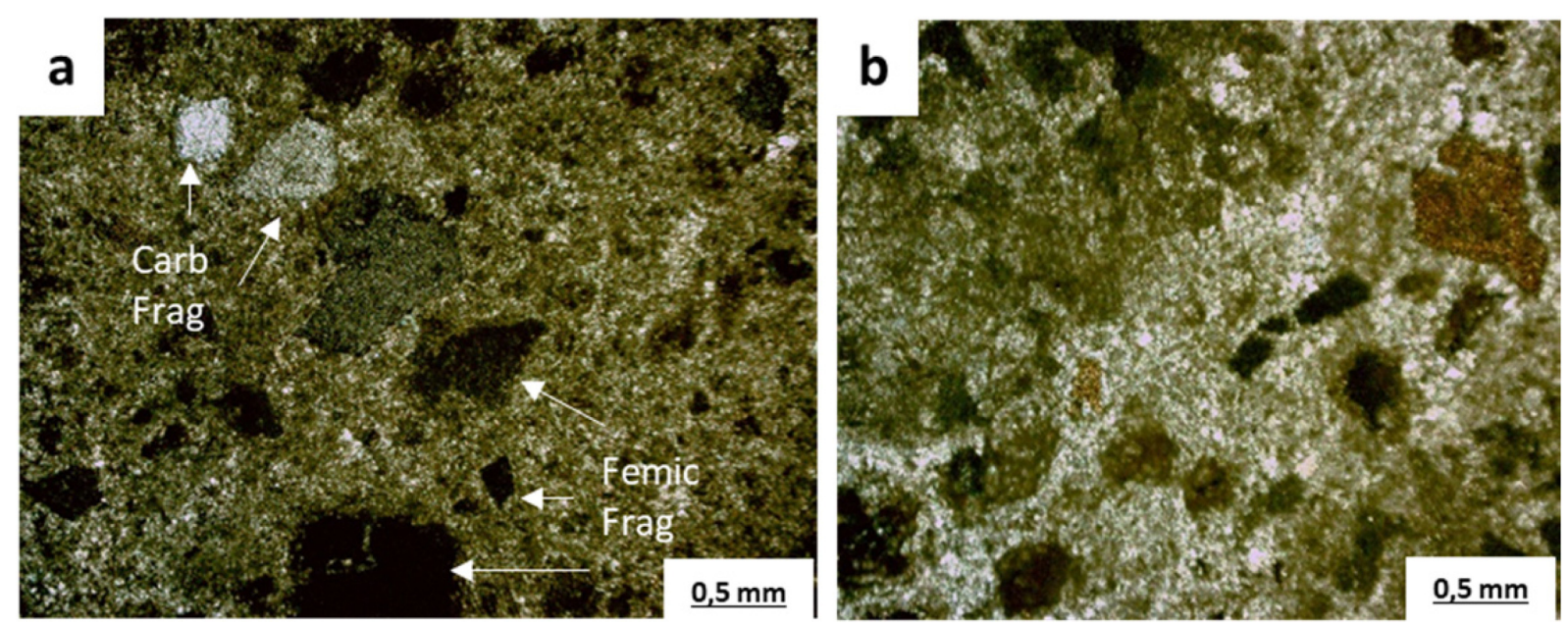

Figure 7. "Fake Ceppo di Grè" samples CO2, C74, CO7. Thin section observations: a) carbonate fragments and femic fragments in a greenish matrix. b) carbonation phenomena and greenish areas. Greenish color is probably due to alteration process of aggregates in the matrix. 

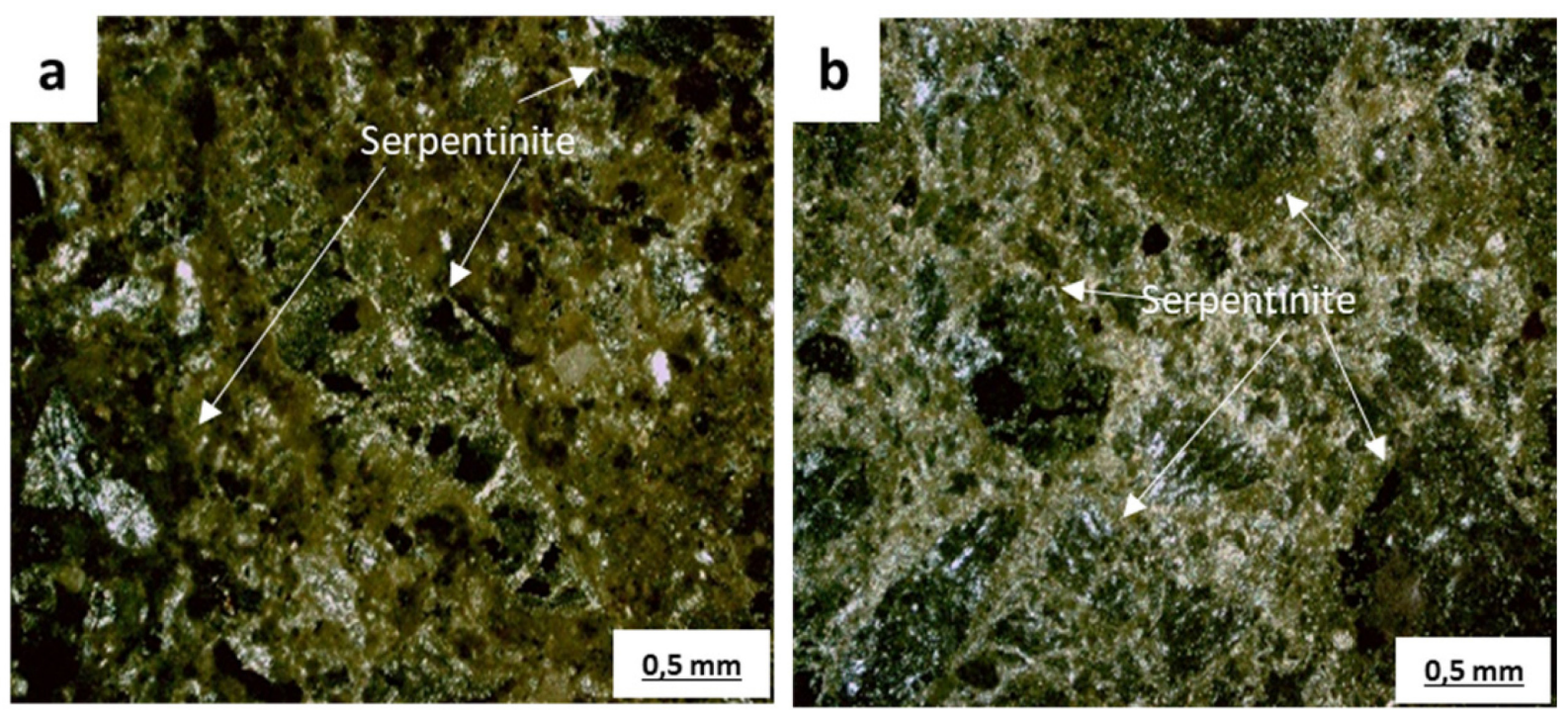

Figure 8. Fake limestone sample CO6. This section observations reveal a great Yang et al. (2019) quantity of serpentine mineral phases in the mixture.

binder modal ratio was approximately $1 / 3$, and the mix appeared highly homogeneous (Fig. 8).

\section{Concrete infilling mortar (Fig. 5)}

Despite the high quality of these artificial stone materials, in "fake travertine" and "fake Ceppo di Grè" types, macroscopic observations revealed the decay process of the reinforced concrete base structures with cracking fragility. The infill materials used for restoration with fibrous minerals were present in restricted and localized areas, with a maximum extension of $10 \mathrm{~cm}$ in diameter and thicknesses less than 4 $\mathrm{cm}$. Stereomicroscopic observations of sample CO3, infilling mortar, allowed us to identify fibrous phases that favored macroporosity, which was presumably related to colonization with lithophagous fauna responsible for biodegradation decay. For these samples, thin sections were not made, to avoid the risk of fiber dispersion during the lapping and pol-
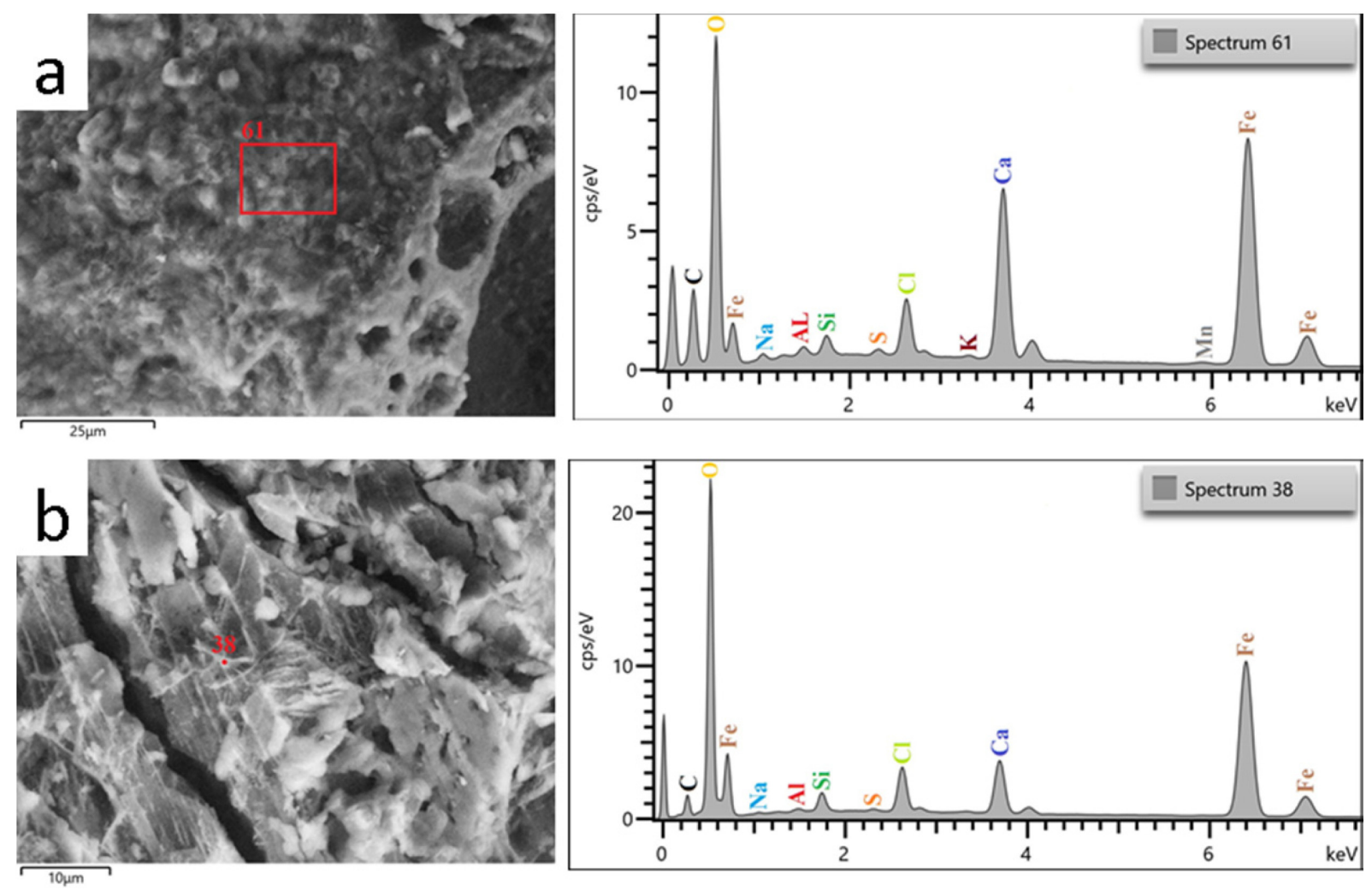

Figure 9. "Fake travertine" Layer A. a) Secondary micrograph of the matrix in the concrete substrata showing the iron oxychloride complexes around and inside a vacuolar structure with corresponding the SEM-Energy Dispersion Spectroscopy (EDS) spectra. b) Secondary micrograph showing layered two-dimensional iron oxychloride (FeOCl) husk like structured. 
ishing operations. Therefore, the analysis was performed by combining microscopic observations with SEM analysis to confirm the presence of asbestos minerals.

\section{SEM-EDS Data Analysis}

\section{"Fake travertine" artificial stone}

Layer A: the corrosion products of reinforcement steel bar were typical layered structures with red and brownish-red color (Fig. 9). This finding was consistent with the iron mobilization from reinforcement steel bars, presumably as a result of capillary action of water, that characterizes the lithological substratum where this edifice was built. These globular clusters were observed in pores of "fake travertine" as well as in the corrosion products of steel reinforcement.

Layer B: the components of the mix design were white cement paste, carbonate aggregate rocks, and yellow pigments, such as iron hydroxides (Fig. 10).

In the samples subjected to SEM observation, EDX analysis revealed iron hydration products with a self-oriented flower shape with an average diameter of 10-12 $\mu \mathrm{m}$ (Fig. 11).

\section{"Fake Ceppo di Grè"}

Two types of sulfates was recognized: calcium sulfate (Fig. 12) and barium sulfate (Fig. 13). The EDS spectra of these particles demonstrated a high-amount of sulfate in these black points.
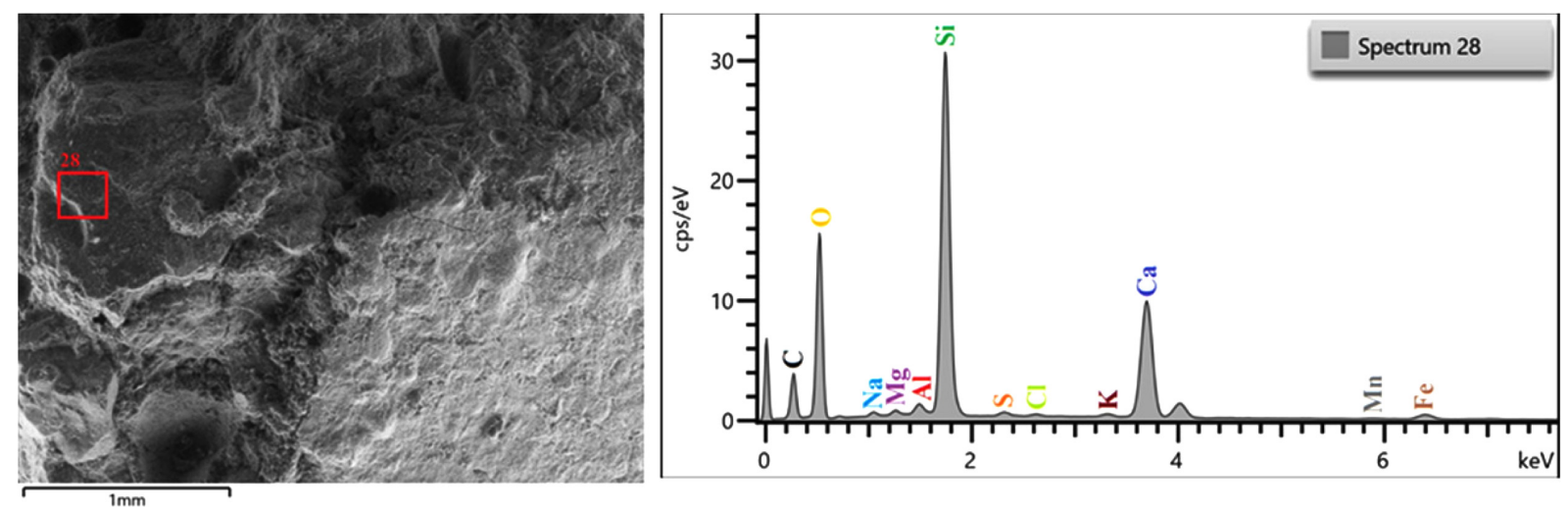

Figure 10. "Fake travertine" Layer B. Secondary micrograph showing the composition of amorphous white matrix and the corresponding the SEM-Energy Dispersion Spectroscopy (EDS) spectra.
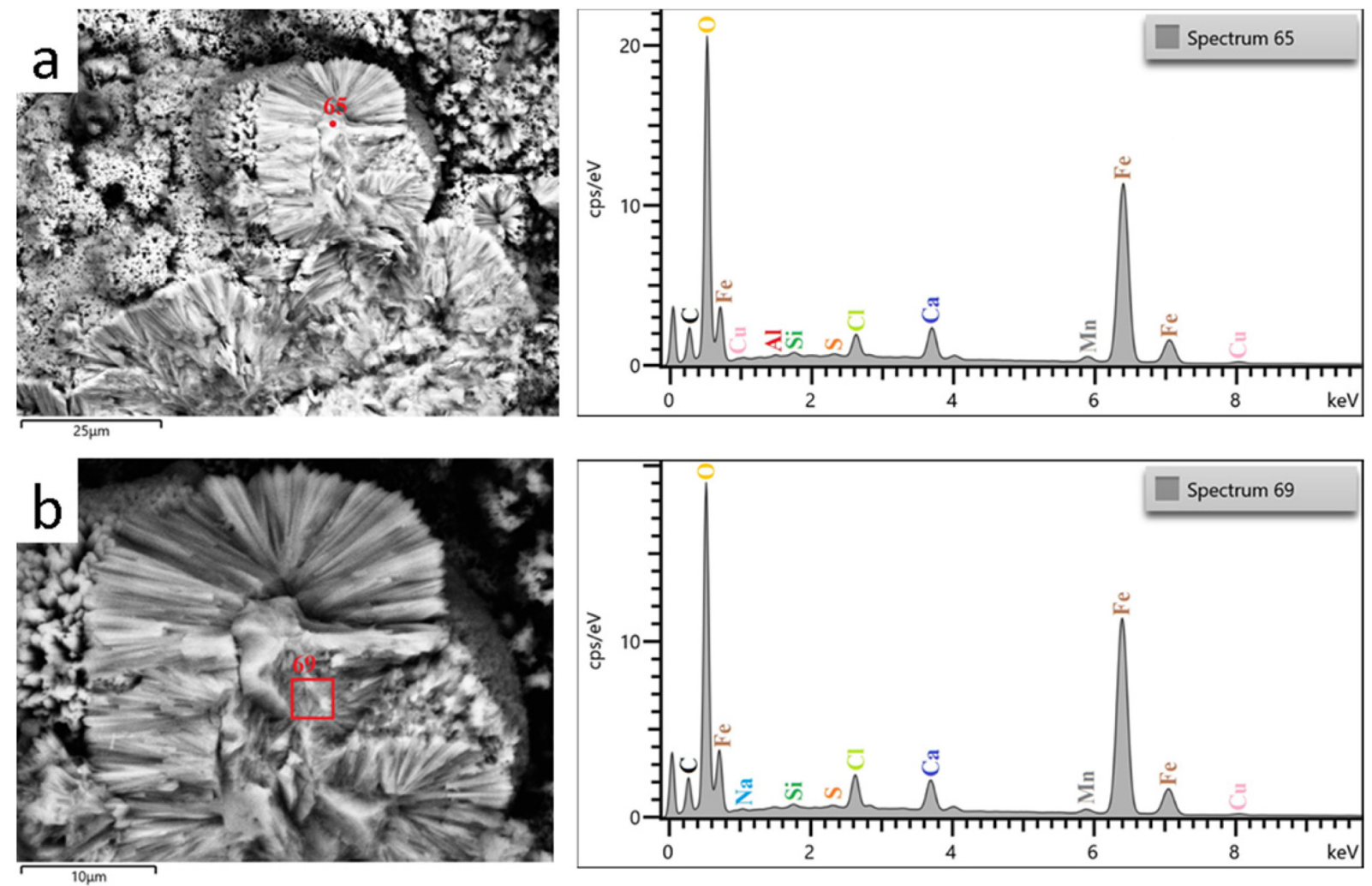

Figure 11. "Fake travertine" Layer B. a) and b) BSE micrographs showing the iron oxychloride complexes with the self-oriented flower shape with average diameter of 10-12 $\mu \mathrm{m}$ and the corresponding the SEM-Energy Dispersion Spectroscopy (EDS) spectra. 

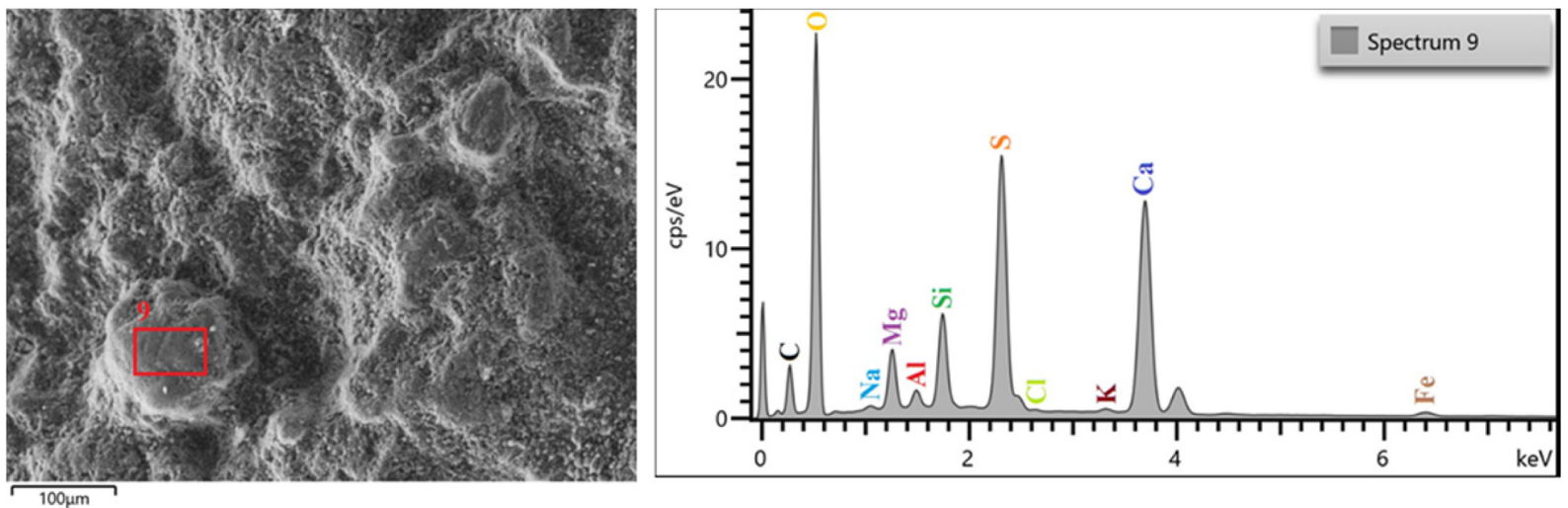

Figure 12. "Fake Ceppo di Grè". Secondary micrograph showing calcium sulphate as indicated by SEM-Energy Dispersion Spectroscopy (EDS) spectra indicating a high-amount of sulphate for this portion of sample.
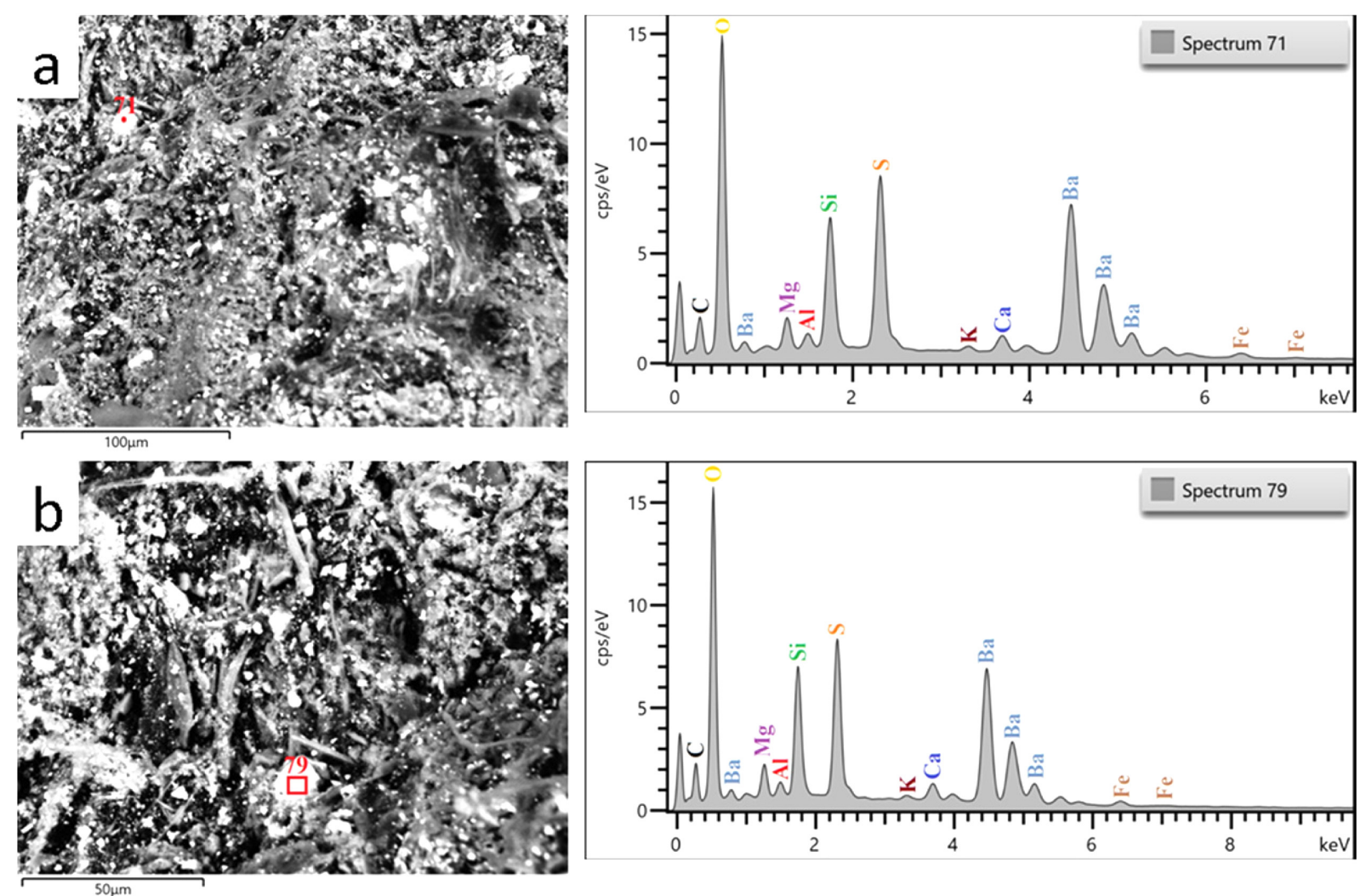

Figure 13. "Fake Ceppo di Grè". A) and b) BSE micrographs showing presence of barium sulphate phases as confirmed by SEM-Energy Dispersion Spectroscopy (EDS) spectra. The barium hydroxide mixture has been added to make the concrete harder and therefore resistant to physical and mechanical stress and degradation.

\section{Concrete Infilling Mortar}

Because stereomicroscopic observation revealed the presence of fibrous phases, SEM-EDS analysis was performed to better identify the chemical. Fig. 14 shows back scattered images highlighting the presence of various fiber types and confirming the microscopic observations. In these samples, asbestos tailings mainly contained serpentine, including snakesite, antigorite and chrysotile, as well as small amounts of brucite, magnetite, quartz, talc, and chlorite. The main chemical composition of the asbestos tailings was $\mathrm{SiO}_{2}, \mathrm{MgO}$, and $\mathrm{Fe}_{2} \mathrm{O}_{3}$, with a small amount of $\mathrm{Al}_{2} \mathrm{O}_{3}$ and $\mathrm{CaO}$.

\section{Fake Limestone Used for Columns}

Thin section observations showed a white cement mortar with amorphous structure and a well-classed medium silica sand aggregate enriched in serpentinite. SEM analyses revealed a composition compatible with the presence of tremolite-actinolite amphibole group phases (Fig. 15). SEM analyses also confirmed the use of pale green and white leaded glass (Fig. 16).

\section{XRPD Data Analysis}

XRD patterns of sample CO3 (Fig. 17) revealed peaks of lizardite 

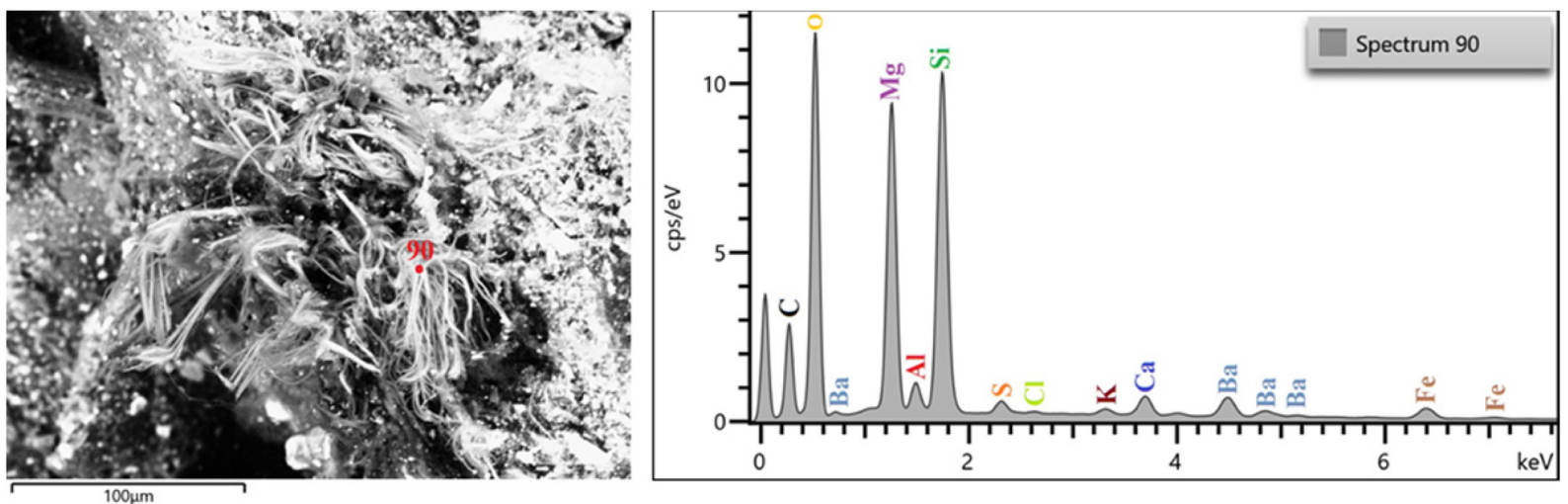

Figure 14. Concrete infilling mortar. BSE micrograph showing fibrous minerals presumably of asbestos phases, SEM-Energy Dispersion Spectroscopy (EDS) spectra revealed high peaks in Mg and Si, with minor peaks of Ti and Al coherent with phases belonging to serpentine group.
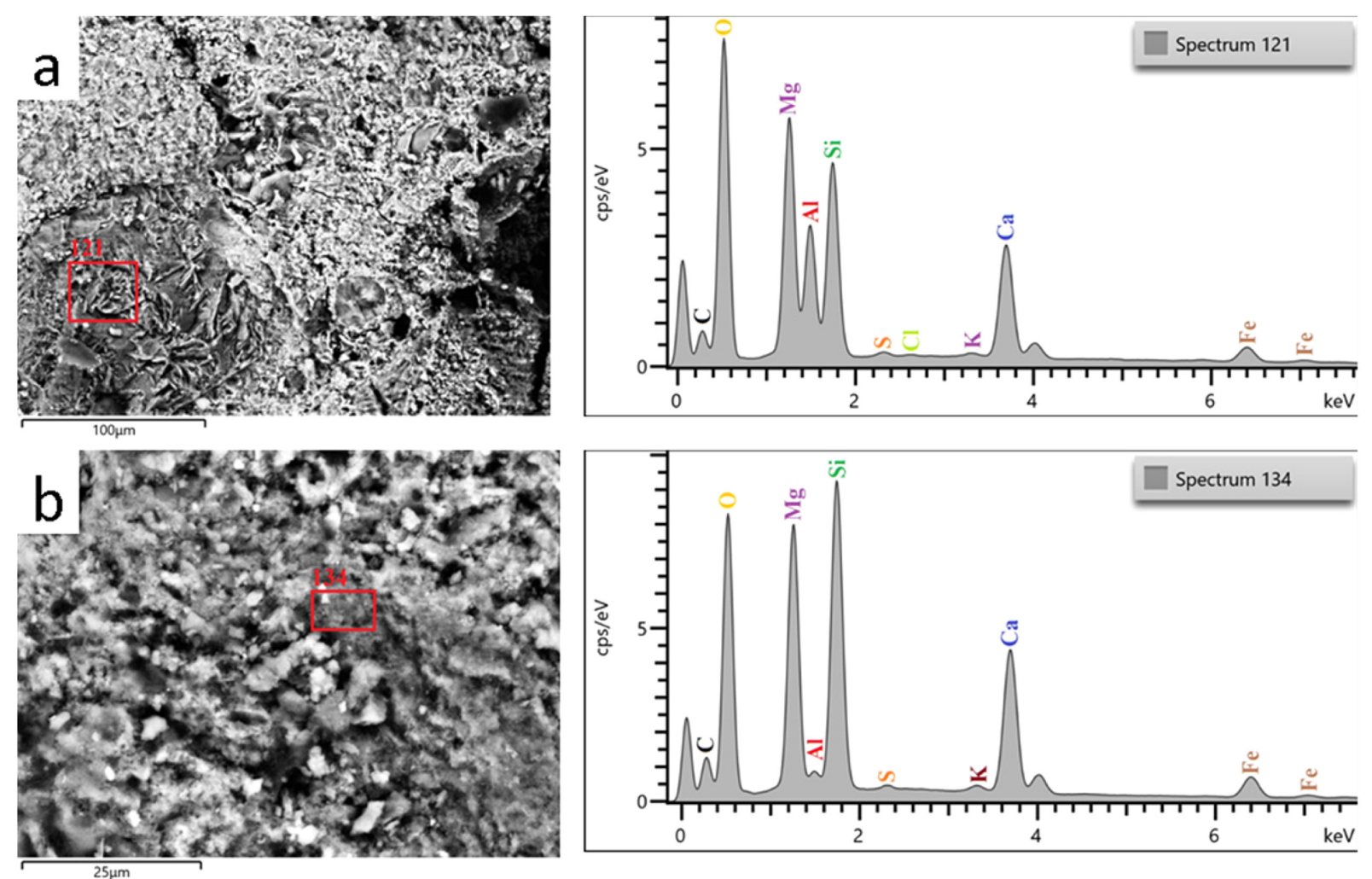

Figure 15. Fake limestone used for columns. A) and b) Secondary micrographs showing minerals presumably of asbestos phases, SEMEnergy Dispersion Spectroscopy (EDS) spectra revealed high peaks in Mg, Si and Ca, this in accordance with composition of same amphibole belonging to tremolite-actinolite group.

$\left(\mathrm{Mg}_{3} \mathrm{Si}_{2} \mathrm{O}_{5}(\mathrm{OH})_{4}\right)\left(2 \theta\right.$ at $12^{\circ}$ and $\left.24^{\circ}\right)$, a polymorph of the serpentine group minerals.

\section{Discussion}

The combination of techniques used in this study to characterize the mixtures used to formulate artificial stones highlighted the typical features of each type of artificial stone. OPLM is the most common analytical technique used by geologists for mineralogical and petrographic characterization of materials. Macroscopic observation indicated the presence of a steel bar-reinforced concrete substratum in almost all of the samples; therefore, we hypothesized that pre-packaged slabs based on cement mortar were used. The bar-reinforced concrete substratum was evident only in the "fake travertine" slabs; the artificial stone mixture was found over this layer. OPLM investigation of the artificial stone material revealed the absence of efflorescence that, as suggested by Morillas et al., 2015 and Chen et al., 2017, may be associated with the use of materials with low salt content as aerators. Optical microscopy observations indicated the presence of asbestos minerals in some analyzed samples, but, as suggested by Militello et al. (2019), this technique is considerably limited for identifying asbestos fibers. Therefore, OPLM was coupled with XRD and SEM analyses to investigate the potential presence of asbestiform 

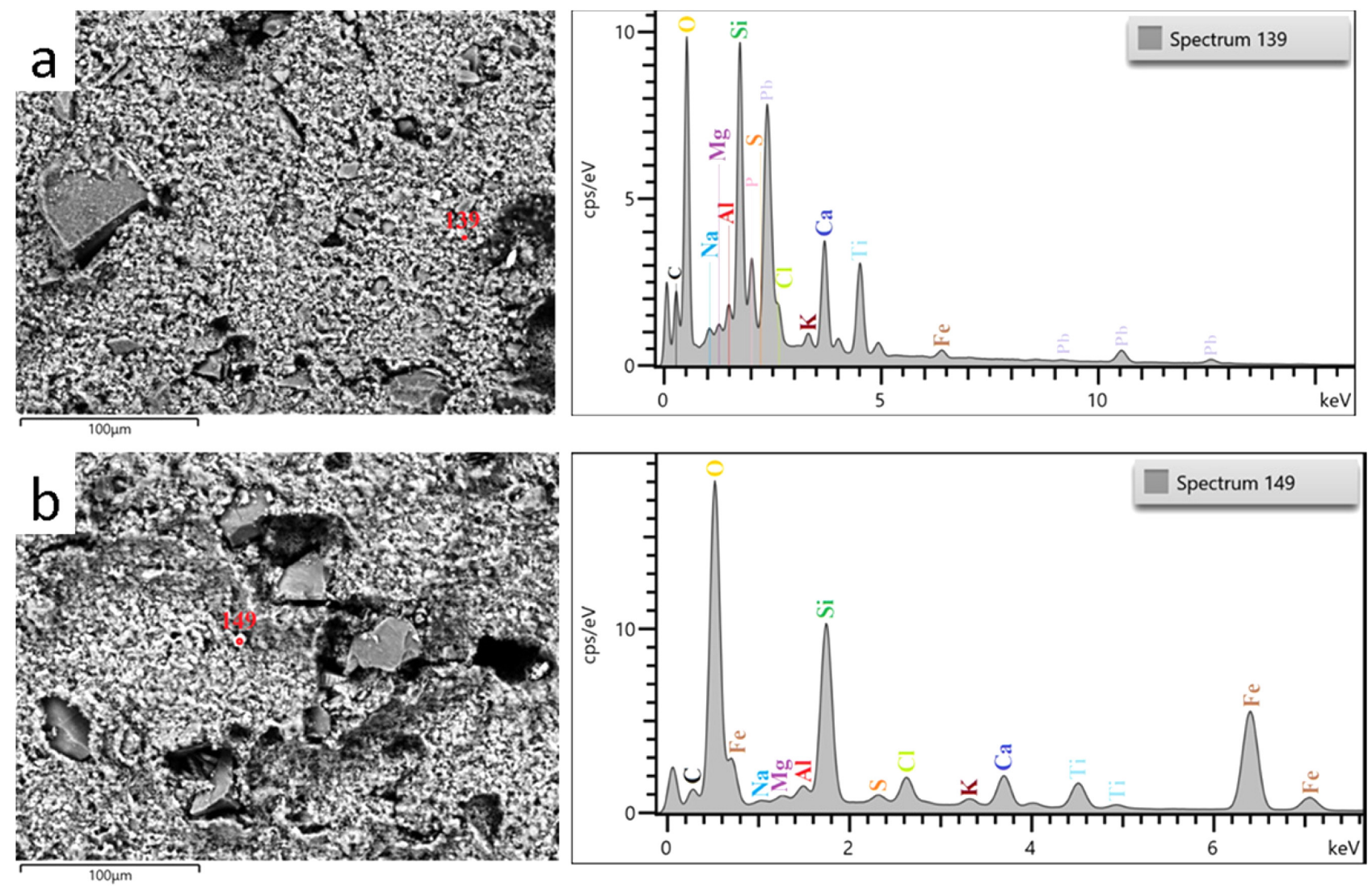

Figure 16. Fake limestone used for columns. A) and b) Secondary micrographs showing presence of glass microparticles in some cases enriched in lead.

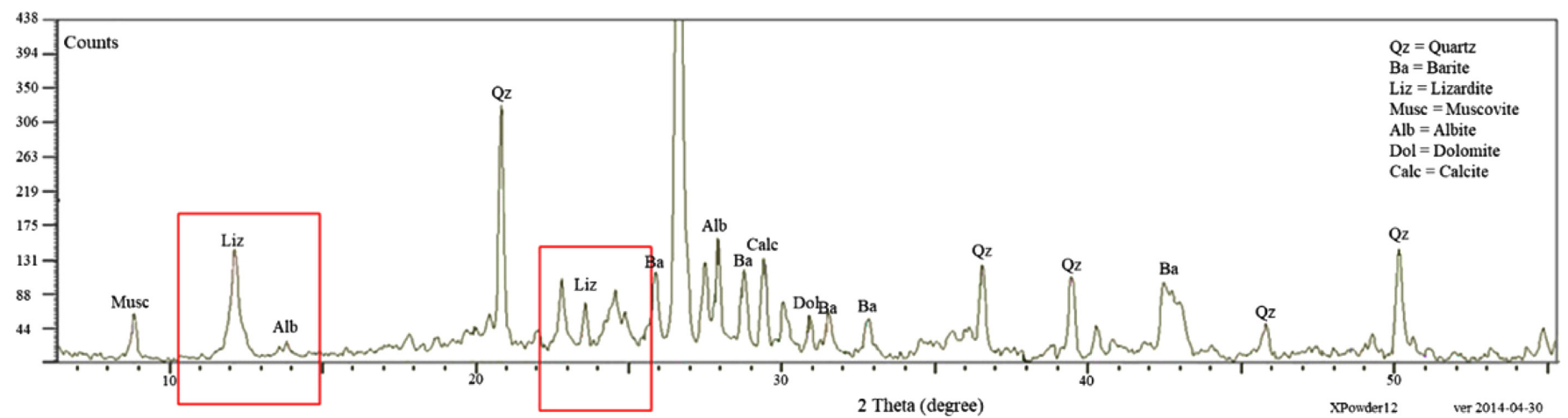

Figure 17. X Ray diffraction pattern. In the red squares are highlighted the peaks of lizardite, confirming the presence of these serpentinite mineral phases in a sample of concrete used for restoring operation.

minerals in concrete infilling mortars and in fake limestone used for columns. In both types of samples, SEM-EDS data showed high peaks of $\mathrm{Mg}$ and $\mathrm{Si}$ that may indicate the presence of asbestos at the fibrous elements, but a distinction must be made: in the fake limestone samples, asbestos mineral phases may be associated with weathering processes of ultramafic rock minerals characterizing the aggregate, because lizardite is commonly the main polymorph present in serpentinites (Schwartz et al., 2013). For concrete infilling mortar, the presence of asbestos minerals may be due to the presence of these types of minerals in the starting mixture.

The XRD pattern of a representative sample confirmed the presence of lizardite, one of the three polymorphs of serpentine (Auzende et al., 2004; Votyakov et al., 2005 and Liu et al., 2010; Schwartz et al., 2013; Guillot et al., 2015; Liu et al., 2019), and SEM-EDS analyses characterized the aspect ratios and the textural relationships among the various mineral phases and revealed the presence of different fibrous phases in the studied samples.

SEM-EDS analyses of "fake travertine" samples indicated the presence of iron oxychloride complexes with self-oriented flower shaped markings (Fig. 13). Thus, we hypothesized that iron oxide fibers were present, as reported by Sayed and Polshettiwar (2015), in agreement with iron mobilization from reinforcement steel bars. Oxygen fugacity and $\mathrm{pH}$ may influence the corrosion of iron materials, and chloride might be adsorbed or might penetrate easily through the passive film, 
thus damaging the integrity and subsequently accelerating the electrochemical reactions.

SEM-EDS analyses of "fake Ceppo di Grè" highlighted unusual peaks of $\mathrm{Ba}$, thus suggesting that $\mathrm{Ba}$ hydroxide was added to the mixture to make the concrete harder and therefore resistant to physical and mechanical stress and degradation. The same procedure might have been used for cement, in which barium may be added to help bind and enhance resistance to different types of radiation (Zezulová et al., 2016). Barium cations are a part of the raw mixture and thus can be incorporated into the crystal lattices of alite and belite, and the interstitial phase. Some authors have found neither barium nor ferrite in belite (Juel and Jøns, 2001); only tricalcium aluminate can contain barium in its structure (Katyal et al., 1999). These findings are in accordance with the high $\mathrm{SiO}_{2} /$ calcium in the Ba-rich matrix (spectrum 70-72). Zezulová et al. (2016) have observed that an excessive $\mathrm{BaO}$ concentration can inhibit the crystallization of alite or decompose alite in favor of belite and free lime. The free lime then produces an excess of portlandite, which, in the presence of sulfur in the mixture, justifies the high content of calcium sulfate observed with SEM analyses in this process.

The use of pale green and white leaded glass, as confirmed by SEM analyses, is consistent with the addition of glass fragments to mortar mixtures for aesthetic purposes and with increasing the mortar's resistance to sunlight.

\section{Conclusions}

A combination of different analytical methods were used to characterize the artificial stone materials used in a rationalist architectural building in a rural town near Ferrara in the Emilia Romagna region (northeastern Italy).

Macroscopic observations revealed superficial damage with fractures and cracks, the exposure of degraded and oxidized bar reinforcements, and biological degradation in almost all the artificial stones.

OPLM observations showed different compositions of the aggregate in the various types of artificial stone materials used, thus highlighting the presence of minerals from metamorphosed ultramafic rocks in some samples and filler containing fibrous minerals in other samples.

SEM-EDS and XRD analyses confirmed the presence of asbestos mineral phases, particularly lizardite, both in the concrete used for restoring operations and in samples enriched in ultramafic aggregate.

The observed lizardite fibers did not appear to be present at dangerous levels, but potential risks during restoration or collection should be taken into consideration. In this light, mineralogical and petrographic characterization of building materials is a useful tool for investigating the presence of potentially dangerous fillers that required caution during degradation product removal through sandblasting or other methodologies that pulverize the altered surfaces. To prevent effective post-degradation fracturing and transformation into elements harmful for health and the environment, careful monitoring is recommended.

In conclusion, the overall project, besides providing valuable support for the restoration work, enabled studying an eminent artistic product of epochal monumental architecture - a symbol of recent history now deserving renewed attention.

\section{Acknowledgments}

The authors to thank the anonymous reviewers and the Editors for their advice, suggestions, and patience. We are also grateful to Prof. Ursula Thun Hohenstein for helping with this research project and providing constructive comments on the manuscript, and Mr. Riccardo Mazza of Socotec Italia for support during sampling activities.

\section{References}

Auzende, A.L., Daniel, I., Reynard, B., Lemaire, C., and Guyot, F., 2004, Physics and Chemistry of Minerals, v. 31, pp. 269-277.

Baldazzi, L., 2012, Problemi di Diagnostica e Restauro dei Materiali Decorativi nell'architettura Liberty in Emilia-Romagna. $\mathrm{PhD}$ thesis in Materials Engineering, ciclo XXIV. University of Bologna.

Bartz, W., Rogo, J., Rogal, R., Cupa, A., and Szroeder, P., 2012, Characterization of historical lime plasters by combined non-destructive and destructive tests: the case of the sgraffito in Boznow (SW Poland). Constr Build Mater, v. 30, pp. 439-446.

Baumann, F., and Ambrosi J., 2013, Environmental exposure to mineral fibers in New Caledonia: an ecological study. American Geophysical Union, Spring Meeting 2013, abstract id. B34A-02.

Berra, F., and Carminati, E., 2010, Subsidence history from a backstripping analysis of the Permo-Mesozoic succession of the Central Southern Alps (Northern Italy). Basin Research, v. 22, pp. 952-975. doi.org/ 10.1111/j.1365-2117.2009.00453.x.

Bertolazzi, A., 2013, Artificial Stone in France (1830-1930): A Material between Modernity and Tradition. Journal of Civil Engineering and Architecture, v. 7, pp. 524-534.

Binda, L., Saisi, A., Tiraboschi, C., 2000, Investigation procedures for the diagnosis of historic masonries. Constr Build Mater, v. 14, pp. pp. 199-233.

Biscontin G. and Driussi G., 2006, Pavimentazioni storiche: uso e conservazione: atti del Convegno di studi, Bressanone, 11-14 luglio 2006. v 22 Scienza e beni culturali. Arcadia Ed. ISBN 8895409108, 9788895409108.

Bloise, A., Punturo, R., Catalano, M., Miriello, D., and Cirrincione, R., 2016. Naturally occurring asbestos (NOA) in rock and soil and relation with human activities: the monitoring example of selected sites in Calabria (southern Italy). Italian Journal of Geosciences, v. 135, pp. 268-279.

Bloise, A., Ricchiuti, C., Lanzafame, G., and Punturo, R., 2020, X-ray synchrotron microtomography: a new technique for characterizing chrysotile asbestos. Science of The Total Environment, v. 703, 135675.

Caprotti, F., 2007, Destructive creation: fascist urban planning, architecture and New Towns in the Pontine Marshes. Journal of Historical Geography, v. 33, pp. 651-679. doi.org/10.1016/j.jhg.2006.08.002.

Chen, R., Yang, K., Qiu, X., Zeng, X., Wang, P., Xu, J., and Chen, J., 2017, Degradation mechanism of CA mortar in CRTS I slab ballastless railway track in the Southwest acid rain region of China-Materials analysis. Construction and Building Materials, v. 149, pp. 921-933.

Clinkenbeard, J.P., Churchill, R.K., and Lee, K., 2002, Guidelines for geologic investigations of naturally occurring asbestos in California. California Department of Conservation, California Geological Survey Special Publication 124.

Constantopoulos, S.H., 2008, Environmental mesothelioma associated with tremolite asbestos: Lessos from the experiences of Turkey, Greece, Corsica, New Caledonia and Cyprus. Regulatory Toxicology and Pharmacology, v. 52, pp. 110-115.

Courard L., Gillard A., Darimont A., Bleus J.M., and Paquet P., 2012, Pathologies of concrete in Saint-Vincent Neo-Byzantine Church and Pauchot reinforced artificial stone. Construction and Building Materials, v. 34, 201-210. doi.org/10.1016/j.conbuildmat.2012.02.070. 
Dameri, A., 2012, Il cemento armato e lo "stile nuovo". "Ecco lo stile nuovo come nasce! Non da arzigogoli senza senso; ma da razionali innovazioni!" in Architettura dell'Eclettismo. Studi storici, rilievo e restauro, teoria e prassi dell'architettura, pp 207-240. ISBN 978882075112.

Di Biase, C., Albani, F. L., and Guidolin, L., 2008, Calcestruzzo, calcestruzzo armato, pietre artificiali. Lessico del degrado. In Architetture in cemento armato. Orientamenti per la conservazione, pp. 191-197.

Fatiguso, F., Scioti, A., De Fino, M., and De Tommasi, G., 2013, Investigation and conservation of artificial stone façades of the early XX century: a case study. Construction and Building Materials, v. 41, pp. 26-36.

Fiorentino, S., Grillini, G.C., and Vandini, M., 2015, The National Monument to Francesco Baracca in Lugo di Romagna (Ravenna, Italy): Materials, techniques and conservation aspects. Case Studies in Construction Materials, v. 3, pp. 19-32. doi.org/10.1016/j.cscm. 2015.05.003

Freire-Lista, D.M., and Fort, R., 2019, Historical City Centres and Traditional Building Stones as Heritage: the Barrio de las Letras, Madrid (Spain). Geoheritage, v 11, pp. 71-85. doi.org/10.1007/s12371-018-0314-z.

Guillot, S., Schwartz, S., Reynard, B., Agard, P., and Prigent, C., 2015, Tectonic significance of serpentinites. Tectonophysics, v. 646, pp. 1-19. doi.org/10.1016/j.tecto.2015.01.020.

International Agency for Research on Cancer (IARC), 2009, Asbestos (Chrysotile, Amosite, Crocidolite, Tremolite, Actinolite, and Anthophyllite) IARC Monographs; Arsenic, Metals, Fibers and Dusts; International Agency for Research on Cancer: Lyon, France; pp. 147-167.

Katyal, N.K., Ahluwalia, S.C., and Parkash, R., 1999, Effect of barium on the formation of tricalcium silicate. Cement and Concrete Research, v. 29, pp. 1857-1862.

Jadoul, F., and Gallidoi, M.T., 2008, The Hettangian shallow water carbonates after the Triassic/Jurassic biocalcification crisis: the Albenza formation in the Western Southern Alps. Rivista Italiana Di Paleontologia E Stratigrafia, v. 114. doi:10.13130/2039-4942/5911

Juel, I., and Jøns, E., 2001, The influence of earth alkalis on the mineralogy in a mineralized Portland cement clinker. Cement and Concrete Research, v. 31, pp. 893-897.

Liu, C., Zhang, W., Song, S., and Li, H., 2019, Effects of Lizardite on pentlandite flotation at different $\mathrm{pH}$ : Implications for the role of particleparticle interaction. Minerals Engineering, v. 132, pp. 8-13.

Mazzeo, G., 2018, Resilienza, circolarità, sostenibilità. Urbanistica Informazioni. Special Issue X Giornata di Studio INU "Crisi e rinascita delle città”, a cura di Francesco Domenico Moccia, Marichela Sepe, v. 272, pp. 218-219.

McCann, D.M., and Forde, M.C., 2001, Review of NDT methods in the assessment of concrete and masonry structures. NDT and E Int, v. 34, pp. 71-84.

Michelacci, C., 2000, I manufatti in pietra artificiale tra la fine del XIX e gli inizi del XX secolo. Materie prime, impasti e tecniche di esecuzione. Analisi campione sperimentale in area fiorentina, Tesi di Laurea A.A. 1999-2000, Dipartimento di Architettura-Università di Firenze, Italy.

Militello, G.M., Bloise, A., Gaggero, L., Lanzafame, G., and Punturo, R., 2019, Multi-Analytical Approach for Asbestos Minerals and Their Non-Asbestiform Analogues: Inferences from Host Rock Textural Constraints. Fibers, v. 7, pp. 42. doi:10.3390/fib7050042.

Molina, E., Rueda-Quero, L., Benavente, D., Burgos-Cara, A., RuizAgudo, E., and Cultrone, G., 2017, Gypsum crust as a source of calcium for the consolidation of carbonate stones using a calcium phosphate-based consolidant. Construction and Building Materials, v. 143, pp. 298-311. doi.org/10.1016/j.conbuildmat.2017.03.155.

Morillas, H., Maguregui, M., Trebolazabala, J., and Madariaga, J. M., 2015, Nature and origin of white efflorescence on bricks, artificial stones, and joint mortars of modern houses evaluated by portable Raman spectroscopy and laboratory analyses. Spectrochimica Acta Part A: Molecular and Biomolecular Spectroscopy, v. 136, pp. 1195-1203.

Mossman, B.T., Bignon, J., Corn, M., Seaton, A., and Gee, J.B.L., 1990. Asbestos: scientific developments and implications for public policy. Science, v. 247, pp. 294-301.
Murray, J., and Nelson, G., 2008. Health effects of amosite mining and milling in South Africa. Regulatory Toxicology and Pharmacology, v. 52 , pp. $75-81$.

Muttoni, G., Kent D.V., Jadoul, F., Olsen, P.E., Rigo, M., Galli, M.T., and Nicora, A., 2010, Rhaetian magneto-biostratigraphy from the Southern Alps (Italy): Constraints on Triassic chronology. Palaeogeography, Palaeoclimatology, Palaeoecology, v. 285, pp. 1-16. doi.org/10.1016/ j.palaeo.2009.10.014

National Institute for Occupational Safety and Health (NIOSH), 2008, Asbestos and Other Elongated Mineral Particles: State of the Science and Roadmap for Research; Revised Draft; NIOSH Current Intelligence Bulletin: Washington, DC, USA.

Nolan, R.P., Langer, A.M., Ross, M., Wicks, F.J., and Martin, R.F., 2001, The health effects of chrysotile asbestos: contribution of science to risk-management decisions. The Canadian Mineralogist Special Publication v. 5, pp. 304.

Pecchioni, E., Malesani, P., Bellucci, B., and Fratini, F., 2005, Artificial stones utilised in Florence historical palaces between the XIX and XX centuries. Journal of Cultural Heritage, v. 6, pp. 227-233.

Pollastri, S., Gualtieri, A. F., Vigliaturo, R., Ignatyev, K., Strafella, E., Pugnaloni, A., and Croce, A., 2016, Stability of mineral fibers in contact with human cell cultures. An in situ $\mu$ XANES, $\mu$ XRD and XRF iron mapping study. Chemosphere, v. 164, pp. 547-557.

Punturo, R., Bloise, A., Critelli, T., Catalano, M., Fazio, E., and Apollaro, C., 2015, Environmental implications related to natural asbestos occurrences in the ophiolites of the Gimigliano-Mount Reventino unit (Calabria, southern Italy). International journal of Environmental Research, v 9, pp. 405-418.

Punturo, R., Ricchiuti, C., Rizzo, M., and Marrocchino, E., 2019, Mineralogical and Microstructural Features of Namibia Marbles: insights about Tremolite related to natural asbestos occurrences. Fibers, v. 7, pp. 31. doi:10.3390/fib7040031.

Randazzo, L., Montana, G., Alduina, R., Quatrini, P., Tsantini, E., and Salemi, B., 2015, Flos Tectorii degradation of mortars: An example of synergistic action between soluble salts and biodeteriogens. Journal of Cultural Heritage, v. 16, pp. 838-847.

Rigopoulos, I., Pomonis, P., Tsikouras, B., and Hatzipanagiotou, K., 2006. Comparative evaluation of dolerites from the Pindos and Vourinos ophiolitic rocks for their use as aggregates. Journal of Materials Science and Technology TCG, I, v. 3, pp. 49-61.

Rigopoulos, I., Tsikouras, B., Pomonis, P., Karipi, S., and Hatzipanagiotou, K., 2008, Quantification methods of asbestos fibers in ophiolitic rocks used as aggregates and hazard risk assessment for human health. 26th European Conference of the Society of Environmental Geochemistry and Health, SEGH 2008, Athens, Hellas, 31/3/2008-2/4/2008, Abstracts, 48.

Rocchi, L., 2012, Le pietre artificiali nelle architetture del ventennio fascista. Tecnologia di realizzazione e problemi di conservazione, in La conservazione del patrimonio architettonico all'aperto (atti «Scienza e Beni Culturali», XXVIII, Bressanone 2012), a cura di G. Biscontin e G. Driussi, Venezia, Arcadia Ed., pp. 352-361.

Ronchi, P., Jadoul, F., Ceriani, A., Di Giulio, A., Scotti, P., Ortenzi, A., and Previde Massara, E., 2011, Multistage dolomitization and distribution of dolomitized bodies in Early Jurassic carbonate platforms (Southern Alps, Italy). Sedimentology, v. 58, pp. 532-565. doi.org/10.1111/j.13653091.2010.01174.x

Ross, M., and Nolan, R.P., 2003. History of asbestos discovery and use and asbestos-related disease in context with the occurrence of asbestos within ophiolite complexes. Geological Society of America, Special Paper v. 373, pp. 447-470.

Sandrolini, F., Franzoni, E., Cuppini, G., and Caggiatia, L., 2005, Materials decay and environmental attack in the Pio Palace at Carpi: a holistic approach for historical architectural surfaces conservation. Build Environ, v. 42, pp. 1966-1974.

Sandrolini, F., Franzoni, E., Varum, H., and Nakonieczny, R., 2011, Materi- 
als and technologies in Art Nouveau architecture: Façade decoration cases in Italy, Portugal and Poland for a consistent restoration. Informes de la Construcción, v. 63, pp. 5-11.

Sayed, F.N., and Polshettiwar, V., 2015, Facile and Sustainable Synthesis of Shaped Iron Oxide Nanoparticles: Effect of Iron Precursor Salts on the Shapes of Iron Oxides. Scientific reports, v. 5, pp. 9733 doi:10.1038/ srep09733.

Schuller, M.P., 2003, Nondestructive testing and damage assessment of masonry structures. Struct Masonry Progress in Structural Engineering and Materials, v. 5, pp. 239-251.

Schwartz, S., Guillot, S., Reynard, B., Lafay, R., Debret, B., Nicollet, C., Linari, P., and Auzende, A.L., 2013, Pressure-temperature estimates of the Lizardite/antigorite transition in high pressure serpentinites. Lithos, v. 178, pp. 197-210.

Skarpelis, N., and Dabitzias, S., 1987, The chrysotile asbestos deposit at Zidani, northern Greece. Ofioliti, v. 12, pp. 403-410.

Stanton, M.F., Layard, M., Tegeris, A., Miller, E., May, M., Morgan, E., and Smith, A., 1981, Relation of particle dimensions to carcinogenicity in amphibole asbestoses and other fibrous minerals. Journal of National Cancer Institute, v. 67, 965-975.

Tamiozzo, R., 2009, La legislazione dei beni culturali e paesaggistici: guida ragionata. Giuffrè Editore, v. 80, pp. 552-524.

Turci, F., Favero-Longo, S. E., Gazzano, C., Tomatis, M., Gentile-Garofalo, L., and Bergamini, M., 2016, Assessment of asbestos exposure during a simulated agricultural activity in the proximity of the former asbestos mine of Balangero, Italy. Journal of hazardous materials, v. 308, pp. 321-327.

UNI 11176:2006 Beni culturali - Descrizione petrografica di una malta NORMAL 14/83.

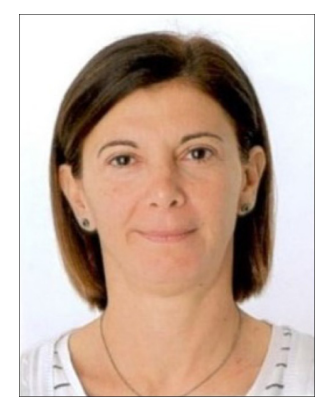

Elena Marrocchino PhD in Earth Sciences. Post-doc researcher at the University of Ferrara, Department of Physics and Earth Science. Areas of expertise are geochemical and petrographic-mineralogical characterization of earth materials: a) for their use as natural and recycled aggregates for use in concrete; b) sediments and soils; c) cultural heritage materials (bricks, mortars, plasters, glass, pigments, metals); d) geochemical and isotopic food traceability.

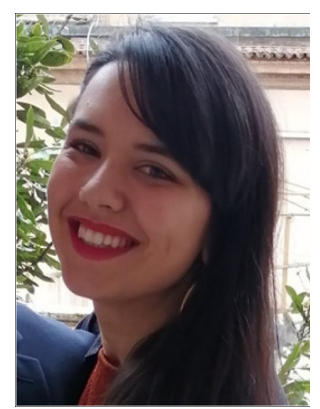

Virginia Lattao Master degree in Quaternary, Prehistory and Archeology with a thesis about archeometric analysis about Iranian Bronze age's pottery. After her graduation, she obtained research grants by the Department of Physics and Earth Sciences and the Department of Human Studies of University of Ferrara and she worked for Consorzio Futuro in Ricerca. She has been involved in terramare archaeological excavations in Bondeno (Ferrara) and in projects focused on characterization of mortars in archaeological and modern contests. She also collaborated with the University Museum System of Ferrara and she is a vice-president of Prehistorica, an association devoted to dissemination.
Tsikouras, B., Pomonis, P., Rigopoulos, I., and Hatzipanagiotou, K., 2005. Investigation for the suitability of basic ophiolitic rocks from the Mikroklissoura Grevena area as anti-skid aggregate material and railroad ballast. Proc. of the 2nd Conference of the Committee of Economical Geology, Mineralogy and Geochemistry, pp. 347-356.

Varas-Muriel, M.J., Pérez-Monserrat, E.M., Vázquez-Calvo, C., and Fort, R., 2015, Effect of conservation treatments on heritage stone. Characterisation of decay processes in a case study. Construction and Building Materials, v. 95, pp. 611-622.

Viganò, P., 1971, Codigoro: cenni storici. Scuola grafica salesiana.

Vola, G., Fiora, L., and Alciati, L., 2009, Stones used in Bergamo architecture. Studia Universitatis Babe-Bolyai, Geologia, 2009, Special Issue, MAEGS - 16 .

Warkea, P.A., Currana, J.M., Turkingtonb, A.V., and Smitha, B.J., 2003, Condition assessment for building stone conservation:a staging system approach. Build Environment, v. 38, pp. 1113-1123.

World Health Organization (WHO), 1986, Asbestos and Other Natural Mineral Fibers; Environmental Health Criteria, 53; World Health Organization: Geneva, Switzerland; p. 194.

Wylie, A.G., Bailey, K.F., Kelse, J.W., and Lee, R.J., 1993, The importance of width in asbestos fiber carcinogenicity and its implications for public policy. American Industrial Hygiene Association Journal, v. 54, 239-252.

Zezulová, A., Stančk, T., Opravil, T., 2016, The influence of barium sulphate and barium carbonate on the Portland cement. International Conference on Ecology and new Building materials and products, ICEBMP 2016. Procedia Engineering, v. 151, pp. 42-49.

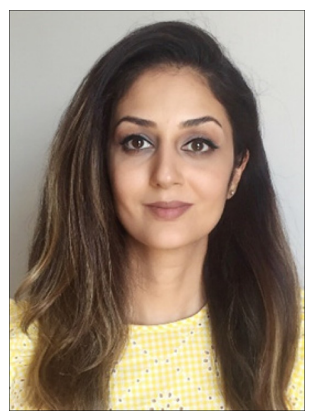

Negar Eftekhari PhD in Science and Technologies for Cultural Heritage, and post doc fellow at the Department of Physics and Earth Sciences at University of Ferrara, Italy. Her field of interst is the application of scientific methods for the identification of cultural materials. She is an expert of using various analytical devices such as SEM-EDS, Micro Raman and micro XRF to respond to various archaeological questions regarding composition, production, use, circulation and manufacturing process of archaeological materials

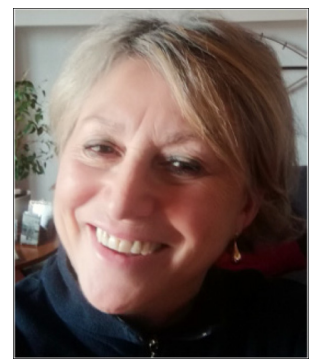

Aida Maria Conte She has thirty years of experience in the minero-petrographic, gechemical and volcanological investigations of magmatic rocks spanning from products of the Roman and Campania Magmatic Provinces (central Italy), to underwater volcanic systems (Pontine Islands, Central Tyrrhenian Sea, Pantelleria Island), up to granite rocks of south-western Sardinia Island (Italy). Part of the activity was also devoted to the characterization and classification, through a multi-analytical approach, of architectural (stone materials and building mortars) and archaeological (amphorae, marble, gems) materials, for the purposes of provenance and restoration. 


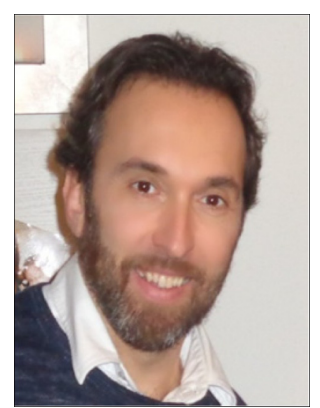

Stefano Franceschini Born in Ferrara (Italy) on 28/07/1974 and residing there. Graduated Mechanical Expert at the State Technical Institute of Ferrara in 1993, he obtained the Master's Office in Civil Engineering hydraulic address in 2000. Enrolled in the Order of Engineers of the Province of Ferrara from $05 / 03 / 2001$. Professionally he alternates experiences in design, construction supervision and safety coordination, for various private customers and public bodies. $\mathrm{He}$ also performs the role of Technical Consultant of the Court of Ferrara. Since 2015 he has been Director of the materials testing laboratory "elletipi" of Ferrara, now part of the multinational group SOCOTEC Italia.

Salvatore Pepi He received the Degree in Geology in 2010 and he completed his $\mathrm{PhD}$ in Earth Sciences at the University of Ferrara in 2014, specializing in environmental geochemistry. His Ph.D. research dealt with the characterization of soil, juice and wine for the determination of elements fingerprints to classify grape varieties according to their geographic origin. He continued this study as research assistant in department of Physics and earth science. His research interests include: environmental geochemistry, evaluation of the trace elements in soil and plant, chemiometric analysis, statistical analysis. $\mathrm{He}$ is author and co-author of papers in national and international journals.

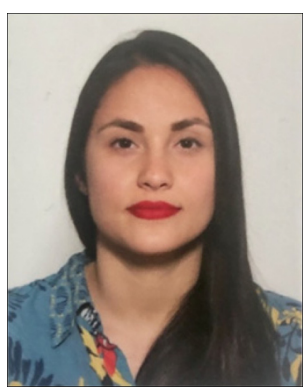

Marzia Rizzo She is a second year PhD student in Earth and Marine Sciences at University of Ferrara and participant in the Interreg Italy-Croatia ECOMAP. Her doctoral research concerns characterization of natural and anthropic materials and investigates the degradation of various types of plastic polymers in different coastal environments to evaluate their impacts. Master's and Bachelor's Degrees in Geology at University of Ferrara. During the Master's thesis, developed within the JPI-CH EMERISDA project, she studied the degradation of mortars and plasters and evaluated the effectiveness of treatments against rising damp in mortars consisting of a polygenic aggregate containing asbestoid materials.

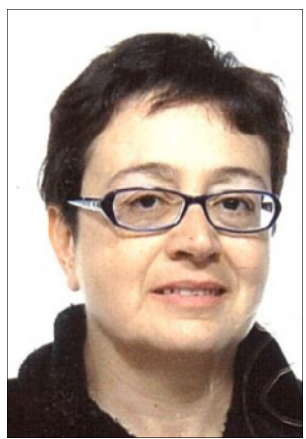

Carmela Vaccaro Associate Professor in "Mining Georesources and Mineralogical Petrographical Applications to Environment and Cultural Heritage" at the Department of Physics and Earth Sciences-Ferrara University. She is involved in research topics regarding the petrology/petrography of magmatic associations and research activities on applied geochemistry and applied petrography: a) archaeometric studies for characterizing the building materials and the damaging products to define the provenance of the raw materials and investigate possible restorations actions; b) projects on desertification problems in the Mediterranean area and evaluation of water quality; c) projects related to chemical-mineralogical characterization of soils and fluvial sediments; d) projects on food traceability. 